\title{
Traditional medicinal knowledge and practices among the tribal communities of Thakht-e-Sulaiman Hills, Pakistan
}

\author{
Khalid Ahmad ${ }^{1 *}$ (D) Mushtaq Ahmad ${ }^{2}$, Franz K. Huber ${ }^{3}$ and Caroline S. Weckerle ${ }^{3}$
}

\begin{abstract}
Background: Little is known about the medical material and practices of tribes in the western border areas of Pakistan. The local population has inhabited this remote and isolated area for centuries, and gained medicinal knowledge with personal experiences and knowledge learned from forefathers. Due to the geographical isolation of the communities in the Sulaiman hills of Pakistan and their unique culture, the area is of importance for exploration and assessment.
\end{abstract}

Methods: A total of 116 informants were interviewed in five foothill villages and the associated migratory mountain villages during 2010-2012 and 2015. Information was gathered mainly through semi-structured interviews and freelisting. Local diseases were categorized based on symptoms and affected organs. Descriptive statistics were used for data analysis.

Results: Depending on the type of illness, typically a pulse diagnoser or a religious specialist is consulted. Medicinal plant knowledge and use is mostly known and advised by elders within the family. A total of 44 plant species from 32 families (588 use reports), 7 animal species and 6 minerals and other sources (384 use reports) were documented as materia medica. Among the plants, the Lamiaceae is the most dominantly used plant family, followed by Pinaceae. The most frequently reported single species was Teucrium stocksianum. The most often mentioned diseases and treatments fall into the categories of gastrointestinal, ritual, and musculoskeletal diseases. The use of goat and sheep skin as medicine was pivotal in the local medicinal system. Remedies from animal parts and other biological and non-biological sources were mainly used for musculoskeletal ailments and ritual treatments. Overall, people rely on both traditional and biomedical medication and treatments and combination of these systems.

Conclusion: This paper provides insight into the pluralistic medication system of rural communities of northwest Pakistan. It highlights the materia medica most commonly in use. A considerable part of the documented materia medica and local practices is part of an oral tradition and cannot be found in written sources or scientific articles. The gaining of new medicinal knowledge in the area was the good sign of continuation of traditional medicinal practices.

Keywords: Ethnobotany, Traditional knowledge, Tribal communities, Thakht-e-Sulaiman Hills

\footnotetext{
*Correspondence: khalidahmad@cuiatd.edu.pk;

khalid.taxonomist@gmail.com

'Department of Environmental Sciences, COMSATS University Islamabad,

Abbottabad Campus, Abbottabad, Pakistan

Full list of author information is available at the end of the article
}

(C) The Author(s). 2021 Open Access This article is licensed under a Creative Commons Attribution 4.0 International License, which permits use, sharing, adaptation, distribution and reproduction in any medium or format, as long as you give appropriate credit to the original author(s) and the source, provide a link to the Creative Commons licence, and indicate if changes were made. The images or other third party material in this article are included in the article's Creative Commons licence, unless indicated otherwise in a credit line to the material. If material is not included in the article's Creative Commons licence and your intended use is not permitted by statutory regulation or exceeds the permitted use, you will need to obtain permission directly from the copyright holder. To view a copy of this licence, visit http://creativecommons.org/licenses/by/4.0/ The Creative Commons Public Domain Dedication waiver (http://creativecommons.org/publicdomain/zero/1.0/) applies to the data made available in this article, unless otherwise stated in a credit line to the data. 


\section{Background}

In rural areas, the local materia medica typically consists of $5-30 \%$ of the plant species of the available flora [1-3]. Further, animals and minerals are also used as medicine [4]. Local medicinal knowledge and traditional practices are heavily impacted by acculturation and modernization processes, and, if left undocumented, valuable knowledge may get lost for future generations [5]. Traditional health care systems, complemented with western medicine, are widely considered as viable solutions for improving human health in rural areas of developing countries worldwide [6].

Traditional medicinal practices in Pakistan have a long history and are largely based on the Unani Tibb, the Greco-Arab system of medicine. The Unani system relies on the concept of humours and aims for nature and mankind to coexist in a balanced manner. Unani Tibb traces its origins back to Hellenistic Greece. It was later adopted by the Arabs, and was extended to both Europe and Asia. Chinese and Indian medicine enriched it further. It proliferated in India under the Muslim rulers around $1350 \mathrm{AD}[7,8]$. Unani is still significant in Pakistan especially among tribal peoples where it is considered as first line treatment [9-11].

Traditional medicine has been accepted and integrated into the national health system of Pakistan [12]. Professional practitioners must be registered by their respective councils, i.e., the National Council for Unani Tibb and the National Council for Homoeopathy. There are approximately 50,000 registered Hakims/Tabibs (Unani medicine practitioners), 6000 Homoeopaths, 537 Vaids (Ayurveda medicine practitioners), about 28 recognized Tibbia colleges and two Universities in the country [13, 14]. About 457 Tibbi dispensaries and many private clinics provide medication publicly throughout the country with 300-350 Unani and around 300 homoeopathic manufacturing companies producing drugs $[10,12,15]$.

Traditional medicine in Pakistan is popular due to its affordability, availability and accessibility [10]. Around $63 \%$ out-of-pocket expenditure of the public is for health issues, and costs tend to be a major barrier in pursuing suitable health care [16]. The government spends about $2.6 \%$ of GDP on health [17], and their primary health care services play a negligible role in country-side areas. Thus, people in remote areas of Pakistan rely heavily on traditional medicines.

A literature review shows that the majority of ethnomedicinal studies in Pakistan are centered on the Himalaya range $[18,19]$, some studies are reported from the Karakoram [20-22], Hindu Kush [23, 24] and Salt ranges $[25,26]$, while remote tribal areas of the Sulaiman Mountains are neglected. The present study, therefore, aims to investigate and document the traditional medicinal knowledge and approach, and the materia medica among a tribal community in the Thakht-e-Sulaiman hills. This may contribute to our understanding of the medicinal pluralism and traditional use of materia medica in the countryside of Pakistan.

\section{Methods}

Study area

Field research of about 24 months was conducted by the first author from 2010 to 2012 and in 2015 in the tribal areas of northwest Pakistan, the then called Federally Administered Tribal Areas (FATA)- recently (in 2018) merged with province Khyber Pakhtunkhwa. We focused on tribal communities in the very south of FATA, living on the eastern side of the Thakht-e-Sulaiman Mountain, the highest peak (3450 m) of the area (Fig. 1). The foothill area ranges from arid to semi-arid, with $200-500 \mathrm{~mm}$ precipitation mostly in July-August and December-January [27]. Summer starts in May and lasts until September with a mean daily maximum of $40^{\circ} \mathrm{C}$, and winter lasts from November to March with a daily maximum of $5.7-7.6^{\circ} \mathrm{C}$. The weather is generally warmer on the eastern side of the mountain. Vegetation changes from dry sub-tropical to dry temperate from east to west with increasing altitude. The top of the Thakht-eSulaiman is covered with coniferous forests [28].

The research area belongs to the Frontier Region of Dera Ismail Khan (F.R. D.I. Khan), with a total area of $2008 \mathrm{~km}^{2}$ and a population of approximately 68,556 [29]. Two tribes live in this area, the Sherani (شيرانئ) in the west and the Ustranas (اؤسترانىئ) in the east [30]. The Sherani area is divided into plains and hills. This study focuses on the hills of the Sherani area which are inhabited by three sub-tribes: the Oba Khel- اوباخيل (ca. 18\% area), Hussan

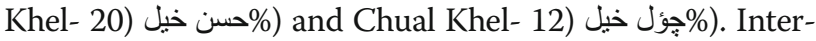
views were conducted among the Sulthan Zai (سلطان زئ) sub-tribe of Oba Khel, which lives in an area of approximately $145 \mathrm{~km}^{2}$ [31].

Interviews were conducted in five foothill villages i.e., Payor Mela, Landi Kutherzai, Zindawar, Jaty Ghbazh and

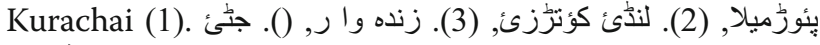
between 1000 and 1200 masl and the associated 'migratory villages' in the mountains between 2300 and 2600 masl, where some people migrate in summer with their herds (Fig. 1). Livelihood strategies include livestock raising, timber cutting, non-timber forest products collection and labor work on daily wages. The informants' details, demographic situation and brief description of foothill villages are shown in Table 1 (for migration and other details of the study sites; see $[28,31]$.

\section{Interviews}

A total of 116 informants between 20 and 100 years with an average age of $41(\mathrm{SD} \pm 13)$ years was interviewed. In 


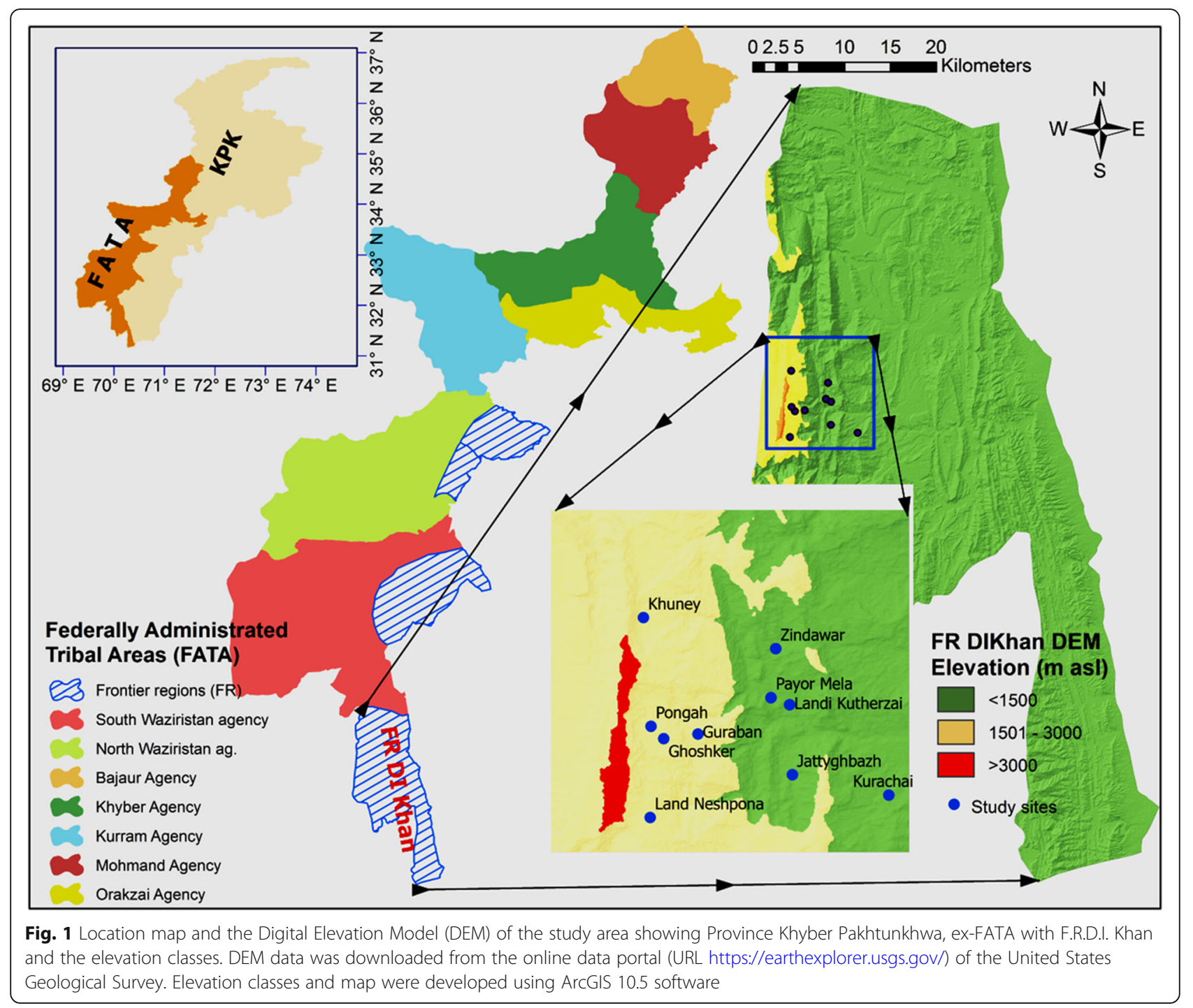

the first phase, unstructured and semi-structured, formal and informal in-depth interviews $(n=58)$ [32] were conducted with informants in the local language, Pashtu. Also, personal observations and group discussions were held to get an overview of general concepts of natural phenomena and familiarize with local terms and their emic definitions [33]. In the second phase, detailed interviews were conducted with local health care specialists for understanding the local health care system in the area $(n=11)$. In the third phase, successive oral freelists were performed with individuals of each village to check for completeness of the collected knowledge as well as its variation at individual and community level $(n=47)$. Transect walks were made along the villages with key informants both at foothills and mountainous areas for specimens' collections and triangulation of data. Most informants were male due to cultural restrictions on involving female informants. Key female informants were included indirectly, mostly through interviewing their sons.

We built rapport with the local communities and were allowed to live with the people, accompany them during their daily life, and attend ritual ceremonies. The ethical guidelines of the International Society of Ethnobiology [34] were strictly followed during the whole research process. Consent was obtained from every informant before interviewing where objectives, procedure and methodology of the project were also explained.

\section{Plant specimens}

Specimens were prepared of all documented plants (Table 5). These were identified by taxonomists at Quaid-I-Azam University Islamabad Pakistan (by Dr. Zahid Ullah \& Dr. Mushtaq Ahmad) and reconfirmed by comparing with specimens in the Herbarium of Pakistan and the Flora of Pakistan $[45,46]$. Families were 
Table 1 Comparison of demographic situation and description about each foothill village

\begin{tabular}{|c|c|c|c|c|c|}
\hline Village name & Payor Mela & Landi Kutherzai & Zindawar & Jatty Ghbaz & Kurachai \\
\hline Village size (No. of families) & 36 & 55 & 21 & 42 & 25 \\
\hline Sample size (No. of informants) & 22 & 35 & 11 & 25 & 12 \\
\hline Informants age (mean $\pm \mathrm{SD}$ ) & $43.54 \pm 16.38$ & $39.72 \pm 15.94$ & $45 \pm 15.11$ & $39.65 \pm 12.38$ & $35.83 \pm 9.73$ \\
\hline Number of family members (mean \pm SD) & $14.92 \pm 5.64$ & $12.44 \pm 6.65$ & $15.67 \pm 6.38$ & $14.75 \pm 6.25$ & $10 \pm 2.48$ \\
\hline Migration ratio (\%) & $\begin{array}{l}50 \\
\text { (to mountains) }\end{array}$ & $\begin{array}{l}61 \\
\text { (to mountains) }\end{array}$ & $\begin{array}{l}50 \\
\text { (Within foothills) }\end{array}$ & $\begin{array}{l}38 \\
\text { (Within foothills) }\end{array}$ & 0 \\
\hline Bilingualism (\%) & 54 & 25 & 1 & 24 & 8 \\
\hline $\begin{array}{l}\text { Average/month/head expenditure } \\
\text { (in PKR; } \pm \text { SD) })^{1 /}\end{array}$ & $931 \pm 212$ & $1063 \pm 370$ & $941 \pm 194$ & $1166 \pm 537$ & $1420 \pm 457$ \\
\hline $\begin{array}{l}\text { Dependency on livestock as a source of } \\
\text { income }{ }^{2)}\end{array}$ & $75 \%$ & $64 \%$ & $87 \%$ & $55 \%$ & $67 \%$ \\
\hline $\begin{array}{l}\text { Dependency on Non-Timber Forest Products } \\
\text { (NTFPs) as a source of income }\end{array}$ & $24 \%$ & $39 \%$ & $25 \%$ & $24 \%$ & $8 \%$ \\
\hline Elevation (meters above sea level) & 1116 & 1052 & 1146 & 1155 & 1184 \\
\hline Population density & Moderate & Densely populated & Less populated & Moderate & Densely populated \\
\hline Vegetation cover & Moderate & Thin vegetation & Dense vegetation & Above moderate & Thin vegetation \\
\hline Soil type & Mostly stony & Clay soil & Diverse types of soil & Mostly stony & Totally stony \\
\hline
\end{tabular}

1) 1 PKR $=0.009527$ USD (December 31, 2015)

2) $75 \%$ dependency on livestock means that $75 \%$ of the households depend on livestock as their main income source. Similarly, $24 \%$ dependency on NTFPs mean that $24 \%$ of households depend on selling NTFPs as main income source

assigned according to Chase et al. [47] and species names were cross checked with The Plant List [48]. All voucher specimens with accession numbers were deposited at the Herbarium of Pakistan (ISL), Quaid-I-Azam University Islamabad Pakistan.

\section{Data analysis}

Information on medicinal plants was analyzed using use reports (URs- as in Table 3, 4,5). One use report corresponds to a specific plant part administered in a specific way against a disease as mentioned by one informant. Freelist data were analyzed using descriptive statistics. To determine the most frequently used plant species for treating a particular ailment category by the informants of the study area, we calculated the fidelity level (FL-, as in Table 6) by following Alexiades [49]. The availability of species was categorized into frequent, occasional, and rare based on personal observations in the field and discussions with the informants by following the criteria of DAFOR scale. Local terms for diseases were reconfirmed with the regional medical doctors. To facilitate crosscultural comparisons and to highlight uniqueness and similarities, we categorized all the diseases mentioned by the interviewees into 16 disease categories according to the symptoms they cause and the organs they affect [50]; see Table 2).

\section{Results}

\section{Local healthcare system}

The local health care system is pluralistic and consists of different types of specialists with different backgrounds. According to their needs, local people visit one or several of these specialists. The choice of medicine is based on severity of disease, effectiveness of the medicine and ease of availability. Wearing the skin of a goat/ sheep is usually applied in severe cases, medicinal plants are used for moderate ailments, and minerals and other animal products are used for specific ailments or as alternatives if plants are unavailable.

Two types of ritual specialists are found: a) Mullayan (ملايان), the religious specialists with formal religious education from a religious school called Madrasa (مدرسان). He uses religious knowledge for healing including the scripture from the holy books and practices from Quran, Hadith, and Sunnah; and is responsible for other religious duties like collective prayers and funeral processions. People visit Mulla usually in cases of 'masiyath' (ماسيت) -a group of ailments including any unusual disease believed to be caused by spirits (Jinn), or other soul related illnesses with symptoms like neurological or psychological trauma/disorders, hypervigilance and pervasive feelings of terror-which are treated with 'ta'wiz', dam and du'a' - (تعويذ، دم، دعا), i.e., amulets, blessings, and prayers. The amulets typically consist of a piece of paper with holy inscription wrapped in a cloth and/or leather and hung/fastened around the neck or arm. Most villages have a Mulla and they tend to have average medicinal plant knowledge; all Mulla we met were men, but nowadays women can also attend religious schools. b) Aamel (عامل), is a ritual specialist consulted when people contract unusual diseases related to spirits. They work with rituals which may last up to 40 days. Usually, they are male but female Aamel also exist. Aamel apprentice with experienced Aamel and go 
Table 2 Disease categories based on symptoms and the affected organs

\begin{tabular}{ll}
\hline Symptoms & Disease category \\
\hline Reduces the duration of Typhoid, body coolness, Sun stroke, Sun shock, influenza, General body ailments, & Multisystem \\
piles, diabetes & Dermatological \\
$\begin{array}{l}\text { Applied on small external wounds, to dry them, Papillae, blisters, abscess, pustules, skin allergy, powdered } \\
\text { is spread in joints of kids, applied on skin after plant splinters and spines get penetratied and cause injury }\end{array}$ & Gastrointestinal \\
Stomach ailments/problems, abdominal/stomach gases and pain, constipation/dysentery, diarrhea/loose & Musculoskeletal \\
motion & Ritual \\
Internal injuries and wounds, bones fractures, sprains, strains & Dentistry \\
Voice infection', unusual diseases, masiyath, i.e., diseases caused by spirits (Jinn), evil eye & Fever \\
Teeth diseases, insects in the teeth and teeth bleeding & Ophthalmological \\
High temperature, malaria & Urenogenital diseases \\
$\begin{array}{l}\text { Eye irritations/troubles } \\
\text { Spermatorrhoea }\end{array}$ & Respiratory \\
Cough & Hepatic \\
Jaundice, Hepatitis & Obesity \\
Used against flatulence, obesity & Blood system \\
Low and high blood pressure & Repellent \\
Snakes didn't enter your home, repel mosquitos & Medicinal food \\
Pain in ear & Earache \\
\hline
\end{tabular}

through arduous training. They communicate with spirits, locally called Paerai (يئى ائى), and are widely known as Jinn. These are entities which can cause physical and mental harm to humans but can be tamed by Aamel. These specialists are rare in the area, and usually lack knowledge of medicinal plants.

Consultants or pulse diagnosers identify the ailment through pulse and provide or suggest appropriate treatment with medicinal plants or other drugs, wearing of animal skin, ritual treatment, or biomedical treatment. The consultant's knowledge about pulse is considered as a gift of God which is mostly transferred from generation to generation (usually male). Usually, each village has a consultant/pulse diagnoser. Locals visit consultants when unaware of what ails them. Consultants have good medicinal plant knowledge.

Traditional bone setters adjust broken and disjointed bones. They are rare in the area and their knowledge is inherited from elders. Rural bone setters tend to use medicinal plants whereas urban bone setters use conventional pharmaceuticals.

Traditional midwives or birth attendants - usually one per village - are wise and experienced women invited during childbirth. They are knowledgeable regarding medicinal plants. Biomedical drugs are administered by medically trained doctors in clinics in urbanized areas. Untrained drug sellers are found in every 3rd or 4th village. They also advise usage and administering of drugs.

There are no specific local medicinal plant specialists, but elders have knowledge of medicinal plants and use them in their families. They are mostly old and experienced people who inherit this knowledge from ancestors and other elders.

\section{Local therapeutic concepts and treatments}

The local materia medica is composed of plants, animals, minerals, and other sources while the local etiology revolves around the Unani concept of humours. This concept reached the area through practitioners trained in Unani medicine from united India who settled in remote tribal areas for community services. Their knowledge was incorporated into the knowledge system of the communities (personal communication with Unani medicine experts).

The concept of "bitter" is locally associated with medicine and an often-used proverb says: "everything bitter except poison is good for health while everything sweet except honey is harmful”. 'Voice infection' (j) is another local concept related to health and disease. It assumes that some people's voice has naturally an infectious effect on the patient or his/her wounded body parts. It can happen intentionally or unintentionally. Beside plants, gold or silver is preferentially used to cure or prevent the effect of 'voice infection' (Table 3).

Evil eye is a concept that describes the power of envy and jealousy. Humans obsessed by envy or jealousy can, with their eyesight, harm their fellow men intentionally or unintentionally. A person with evil eye can harm even when they are pleased to see someone or somebody's possessions. Children, mothers during pregnancy before 
Table 3 Other animal and mineral remedies

\begin{tabular}{|c|c|c|c|c|c|c|c|}
\hline $\begin{array}{l}\text { Species/ } \\
\text { Entity }\end{array}$ & $\begin{array}{l}\text { Common } \\
\text { name/Local } \\
\text { name (in } \\
\text { Pashtu } \\
\text { language) } \\
\end{array}$ & Habit & Status & $\begin{array}{l}\text { Disease } \\
\text { category }\end{array}$ & $\begin{array}{l}\text { Parts } \\
\text { Used }\end{array}$ & Use & $\begin{array}{l}\text { URs } \\
\text { (Informants) }\end{array}$ \\
\hline Gold & Gold/ Sra zer & Mineral & $\begin{array}{l}\text { Precious metal, } \\
\text { wear by women } \\
\text { taken from } \\
\text { market }\end{array}$ & Ritual & Gold & $\begin{array}{l}\text { Gold is used directly or put in water for some } \\
\text { time and that water is mixed with flour to } \\
\text { make dough which is wrapped in cloth and } \\
\text { fastened around (Plate 1; E) or near the } \\
\text { infected organ against 'voice infection'. It is } \\
\text { commonly used after the circumcision of male } \\
\text { child against 'voice infection'. }\end{array}$ & $41(41)$ \\
\hline $\begin{array}{l}\text { Gallus } \\
\text { gallus } \\
\text { domesticus }\end{array}$ & $\begin{array}{l}\text { Chicken egg/ } \\
\text { agayi }\end{array}$ & Bird & Domestic & Musculoskeletal & Egg & $\begin{array}{l}\text { It is taken directly or in half boiled condition } \\
\text { for bone healings. Sometimes curcuma longa } \\
\text { rhizome powder is mixed with it. }\end{array}$ & $33(33)$ \\
\hline $\begin{array}{l}\text { mineral- } \\
\text { pitch or } \\
\text { mineral- } \\
\text { wax }\end{array}$ & $\begin{array}{l}\text { mineral-wax } \\
\text { Salajeeth }\end{array}$ & Mineral & $\begin{array}{l}\text { Secreted from } \\
\text { rock cracks and } \\
\text { locally collected }\end{array}$ & Musculoskeletal & $\begin{array}{l}\text { Mineral- } \\
\text { wax }\end{array}$ & $\begin{array}{l}\text { It is sticky tar-like substance of brown color } \\
\text { which is secreted from rocks called mineral- } \\
\text { pitch or mineral-wax. It is eaten directly but } \\
\text { sometimes taken with milk against musculo- } \\
\text { skeletal ailments. }\end{array}$ & $28(28)$ \\
\hline Brass coin & $\begin{array}{l}\text { Brass coin/ } \\
\text { Sorvay paysa) }\end{array}$ & Alloy & $\begin{array}{l}\text { Previous currency } \\
\text { rarely available in } \\
\text { homes }\end{array}$ & Ritual & $\begin{array}{l}\text { Brass } \\
\text { coin }\end{array}$ & $\begin{array}{l}\text { It is one cent of 1950s-60s Pakistani currency. } \\
\text { A hole is made in the mid of it and fiber is } \\
\text { passed though it which is then fasten around } \\
\text { infected organ against 'voice infection'. }\end{array}$ & $23(23)$ \\
\hline $\begin{array}{l}\text { Marketed } \\
\text { mineral } \\
\text { stone }\end{array}$ & $\begin{array}{l}\text { Mineral stone/ } \\
\text { Da nazer dana }\end{array}$ & Mineral & $\begin{array}{l}\text { Small size stones } \\
\text { of red-orange } \\
\text { color available in } \\
\text { markets }\end{array}$ & Ritual & $\begin{array}{l}\text { Mineral } \\
\text { stone }\end{array}$ & $\begin{array}{l}\text { It is wrapped in cloth and fastened around or } \\
\text { near the infected organ as Amulet, against } \\
\text { 'voice infection'. It is rarely available in the } \\
\text { market. }\end{array}$ & $18(18)$ \\
\hline $\begin{array}{l}\text { A specific } \\
\text { common } \\
\text { stone }\end{array}$ & $\begin{array}{l}\text { common stone/ } \\
\text { Sheen kanrai }\end{array}$ & Mineral & $\begin{array}{l}\text { Locally available } \\
\text { near/around } \\
\text { water channels }\end{array}$ & Dermatological & $\begin{array}{l}\text { Stone } \\
\text { powder }\end{array}$ & $\begin{array}{l}\text { Crashed into pieces and sieved through cloth } \\
\text { to obtain powder which is spread on small } \\
\text { wounds on the body for rapid healing. }\end{array}$ & $17(17)$ \\
\hline $\begin{array}{l}\text { Capra } \\
\text { falconeri }\end{array}$ & $\begin{array}{l}\text { Sulaiman } \\
\text { Markhor/ } \\
\text { Gharchanay }\end{array}$ & Animal & Wild & Hepatic & $\begin{array}{l}\text { Bile of } \\
\text { gall } \\
\text { bladder }\end{array}$ & $\begin{array}{l}\text { The fresh bile of gall bladder is taken orally } \\
\text { against hepatitis B and C. Its meat is also } \\
\text { considered good for health. }\end{array}$ & $14(12)$ \\
\hline $\begin{array}{l}\text { Gallus } \\
\text { gallus } \\
\text { domesticus }\end{array}$ & $\begin{array}{l}\text { Chicken soup/ } \\
\text { Yakhni }\end{array}$ & Bird & Domestic & Musculoskeletal & Meat & $\begin{array}{l}\text { It is boiled in water with black pepper powder } \\
\text { and the decoction (chicken soup) is taken } \\
\text { orally for bone healings. }\end{array}$ & $6(6)$ \\
\hline $\begin{array}{l}\text { Erethizon } \\
\text { dorsaum }\end{array}$ & $\begin{array}{l}\text { Porcupine/ } \\
\text { Skonr }\end{array}$ & Animal & Wild & Musculoskeletal & $\begin{array}{l}\text { Body } \\
\text { fats }\end{array}$ & The fats oil is applied on affected organ. & $4(4)$ \\
\hline $\begin{array}{l}\text { Equus } \\
\text { africanus } \\
\text { asinus }\end{array}$ & Ass/ khra & Animal & Domestic & Respiratry & Milk & $\begin{array}{l}\text { Fresh milk of ass is taken directly against } \\
\text { whopping cough. }\end{array}$ & $3(3)$ \\
\hline Silver & Silver/ Speen zer & Mineral & $\begin{array}{l}\text { Precious metal, } \\
\text { wear by women } \\
\text { taken from } \\
\text { market }\end{array}$ & Ritual & Silver & $\begin{array}{l}\text { The silver is wrapped in cloth and fastened } \\
\text { around or near the infected organ against } \\
\text { 'voice infection'. Mostly when gold is not } \\
\text { available then silver is used. }\end{array}$ & $3(3)$ \\
\hline $\begin{array}{l}\text { Ursus } \\
\text { americanus }\end{array}$ & Black bear/ Yaaz & Animal & Wild & Musculoskeletal & $\begin{array}{l}\text { Body } \\
\text { fats }\end{array}$ & The fats oil is applied on affected organ. & $3(3)$ \\
\hline
\end{tabular}

and after childbirth, ill/injured as well as healthy and wealthy people are vulnerable to it. For protection, a religious amulet is mostly used, or sometimes a small temporary black scar is made with coal on the visible part of the skin.

Wearing of goat/sheep skin is locally considered a paramount medicinal tool. It is used for a large number of ailments especially in cases of emergency and complications (Table 4). Generally, goat skin is considered cold and advised to be worn in summer, while sheep skin is warm and is advised for the winter. Use of each can also be advised regardless of the season. According to key informants, use of the skin needs special care, otherwise, the disease may worsen. Wearing the skin needs to be carefully adjusted to the progression of the disease. For example, skin wearing is advised only at the beginning of malaria; advised at the beginning or end of typhoid but not at the climax when symptoms are the strongest. Correct and effective usage is mostly advised by the consultants of the area or by the elders of the family. It is 
Table 4 The use of goat and sheep skin

\begin{tabular}{|c|c|c|c|}
\hline Animal & Disease category & Description & URs (Informants) \\
\hline Sheep & Musculoskeletal & $\begin{array}{l}\text { It is used for all types of Musculoskeletal problems due to falling from } \\
\text { high place, get strong hits during fights etc. }\end{array}$ & $45(45)$ \\
\hline Sheep & Musculoskeletal & $\begin{array}{l}\text { Women wear it after childbirth as it finishes the pain and heal the } \\
\text { internal injuries and wounds. }\end{array}$ & $40(40)$ \\
\hline Sheep & Hepatic & $\begin{array}{l}\text { When the yellowness of the skin gets high then the skin of sheep is } \\
\text { used, or it is used to remove the remaining symptoms of hepatitis } \\
\text { when the patient gets recently recovered. }\end{array}$ & $21(21)$ \\
\hline Goat & Fever & $\begin{array}{l}\text { At the start of malaria, but not after getting } 2-3 \text { days old as then it may } \\
\text { convert it to typhoid and get complicated. }\end{array}$ & $18(18)$ \\
\hline Sheep & Multisystem & $\begin{array}{l}\text { Typhoid but not at the start of it, either towards its end or after it get } \\
\text { finished then to finish its affects in the body. }\end{array}$ & $11(11)$ \\
\hline Goat (in summer), Sheep (in winter) & Musculoskeletal & $\begin{array}{l}\text { Against general pain in the body or bones which is not getting better } \\
\text { since long time. }\end{array}$ & $10(10)$ \\
\hline Goat & Fever & Used against fever at its beginning stage. & $9(9)$ \\
\hline Goat (in summer), Sheep (in winter) & Fever & $\begin{array}{l}\text { Against fever when it gets complicated or when it does not finish with } \\
\text { normal medication, or when body temperature gets very high or reach } \\
\text { to head, or to finish hidden fever. }\end{array}$ & $8(8)$ \\
\hline Goat & Multisystem & In summer, it is used against sunstroke. & $7(7)$ \\
\hline Goat & Multisystem & Used for body cooling when feel extensive hotness inside the body. & $6(6)$ \\
\hline Goat (in summer), Sheep (in winter) & Multisystem & $\begin{array}{l}\text { General body ailments, i.e., to get the weak person's body stronger, } \\
\text { increase resistance against diseases, finish the symptoms of disease. }\end{array}$ & $4(4)$ \\
\hline Goat (in summer), Sheep (in winter) & Ritual & $\begin{array}{l}\text { Black colored skin is to be worn in case of some unusual diseases, e.g. } \\
\text { caused by spirits (Jinn). }\end{array}$ & $3(3)$ \\
\hline Goat (in summer), Sheep (in winter) & Dermatological & $\begin{array}{l}\text { When bitten by a large number of honeybees (usually honeybees' bites } \\
\text { in summer). }\end{array}$ & $3(3)$ \\
\hline Goat & Gastrointestinal & Against acute diarrhea. & $2(2)$ \\
\hline Goat (in summer), Sheep (in winter) & Dermatological & Against acute skin allergy. & $2(2)$ \\
\hline Goat (in summer), Sheep (in winter) & Urinogenital & When menstruation gets abnormal. & $2(2)$ \\
\hline
\end{tabular}

believed that an imbalance of hot/cold usually causes common illnesses. Wearing of the skin influences this balance, smoothens and supports the body according to its requirements, and detoxifies through suction.

Other remedies made from animals include bear and porcupine fats used against musculoskeletal problems, ass milk against whopping cough, and gall bladder bile from the Sulaiman Markhor-a wild goat (Capra falconeri)-against hepatitis B and C (Table 3). Minerals like gold, mineral stone, silver or brass coins are often ritually used for protection against 'voice infection'.

\section{Diversity and use of medicinal plants}

A total of 44 species of plants were documented with 588 use reports (Table 5). The medicinal species are herbs (21 spp.), trees (12 spp.), shrubs (9 spp.), and climbers (2 spp.) which are distributed among foothills (28 spp. with 258 UR) and mountainous areas (16 spp. with 330 UR; Table 5). Among all, a single species (Curcuma longa) is cultivated, three are semi-cultivated, i.e., present both in wild and cultivated form (Ficus palmata, Olea ferruginea, Punica granatum), while the remaining are wild. Majority of the species are frequently available
(23 spp.) while some are occasional (16 spp.) and others rare (5 spp.). Almost half of the plants (28 spp.) are used only in fresh form while the remaining (16 spp.) are used in both fresh and dried forms. Additionally, 16 species among the documented medicinal plants are also used as food (Table 5). All the diseases cured with medicinal plants are categorized into 16 disease categories in which gastrointestinal diseases are the most commonly mentioned (with high number of species and use reports) followed by multisystem and ritual, respectively (Fig. 2). Leaves are mostly used, while gums, resins, latex, and wood-oil also play an important role (Fig. 3).

\section{Preparation and application of medicinal plants}

All the documented medicinal preparations are based on a single plant. Eight different ways of medicinal plant uses/preparations from different plant parts are employed. Most often, plant parts are used unprocessed (e.g., Acacia modesta and Calotropis procera), followed by infusion and decoction (Fig. 4). Medicine is taken orally (24 spp.) or used topically (9 spp.) and some species have both oral and topical applications (9 spp.). Only 


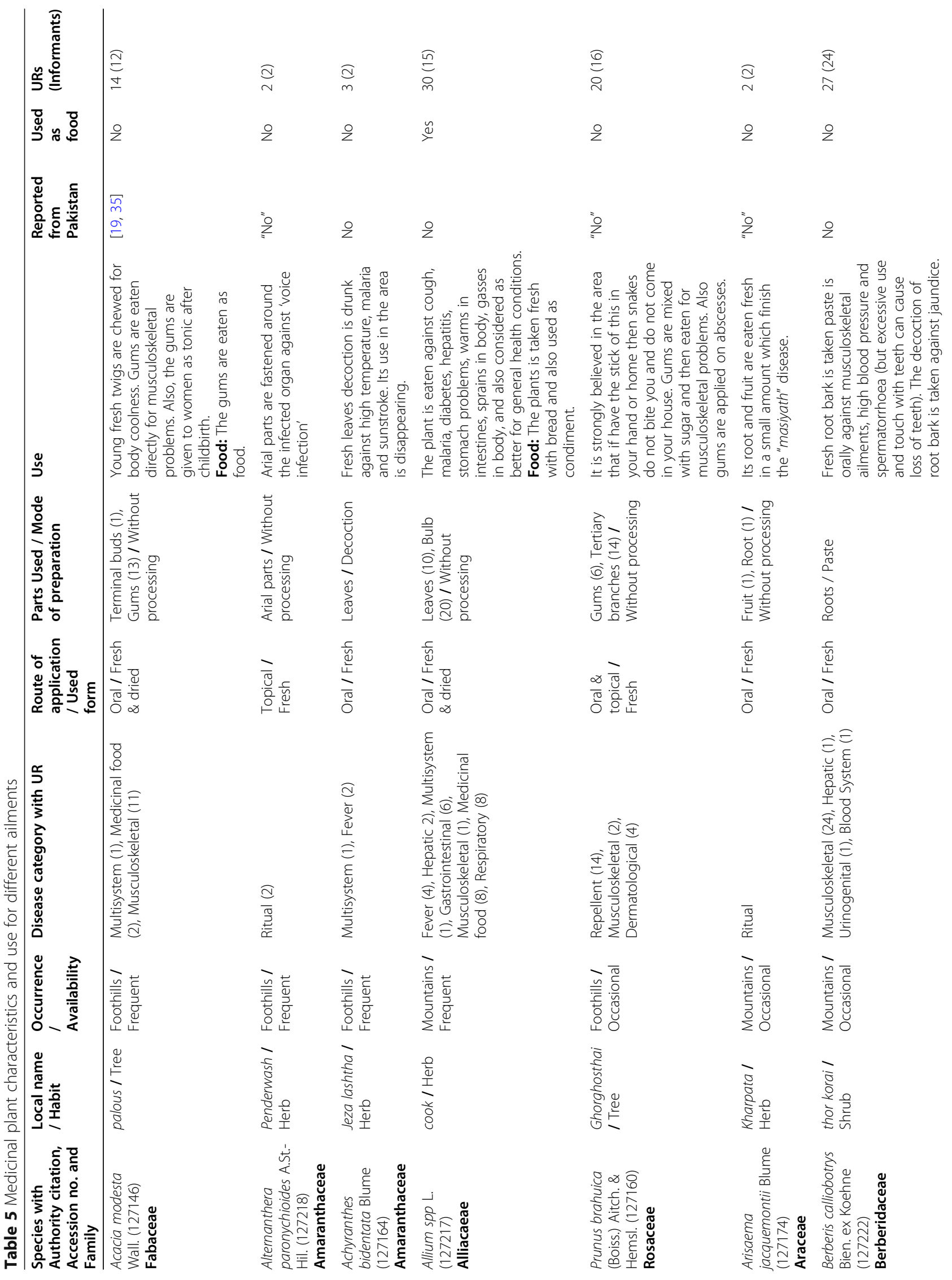




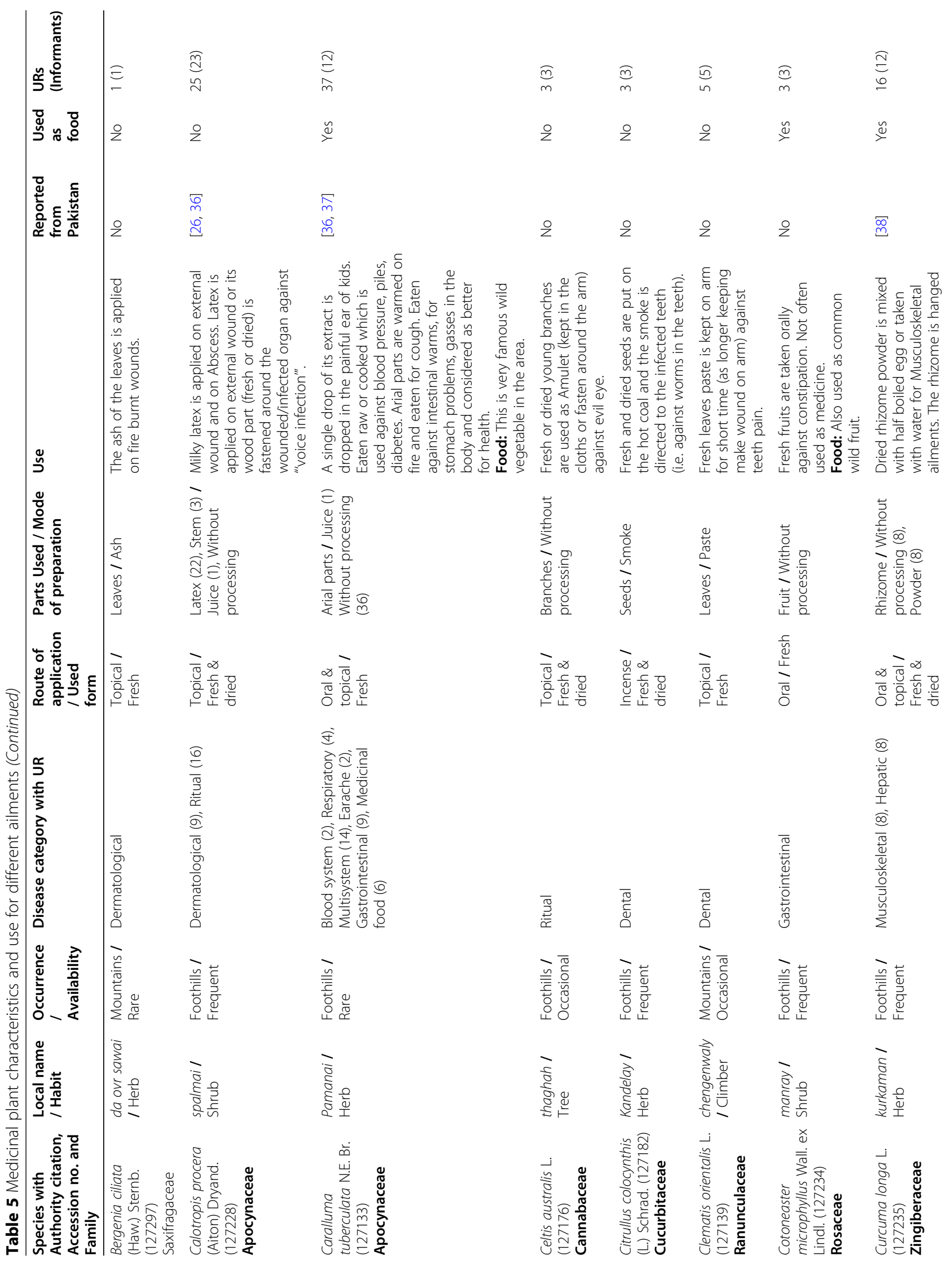




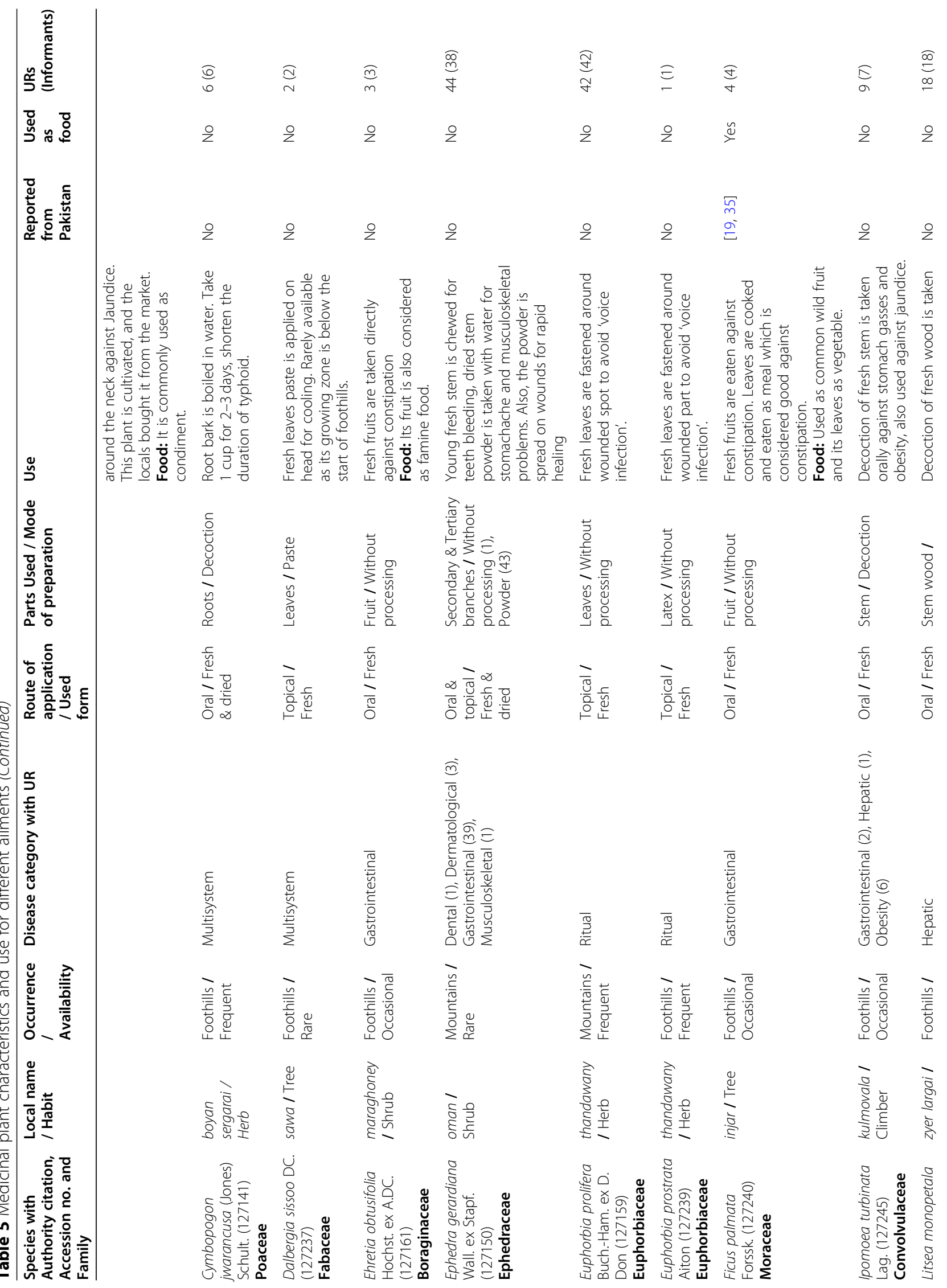




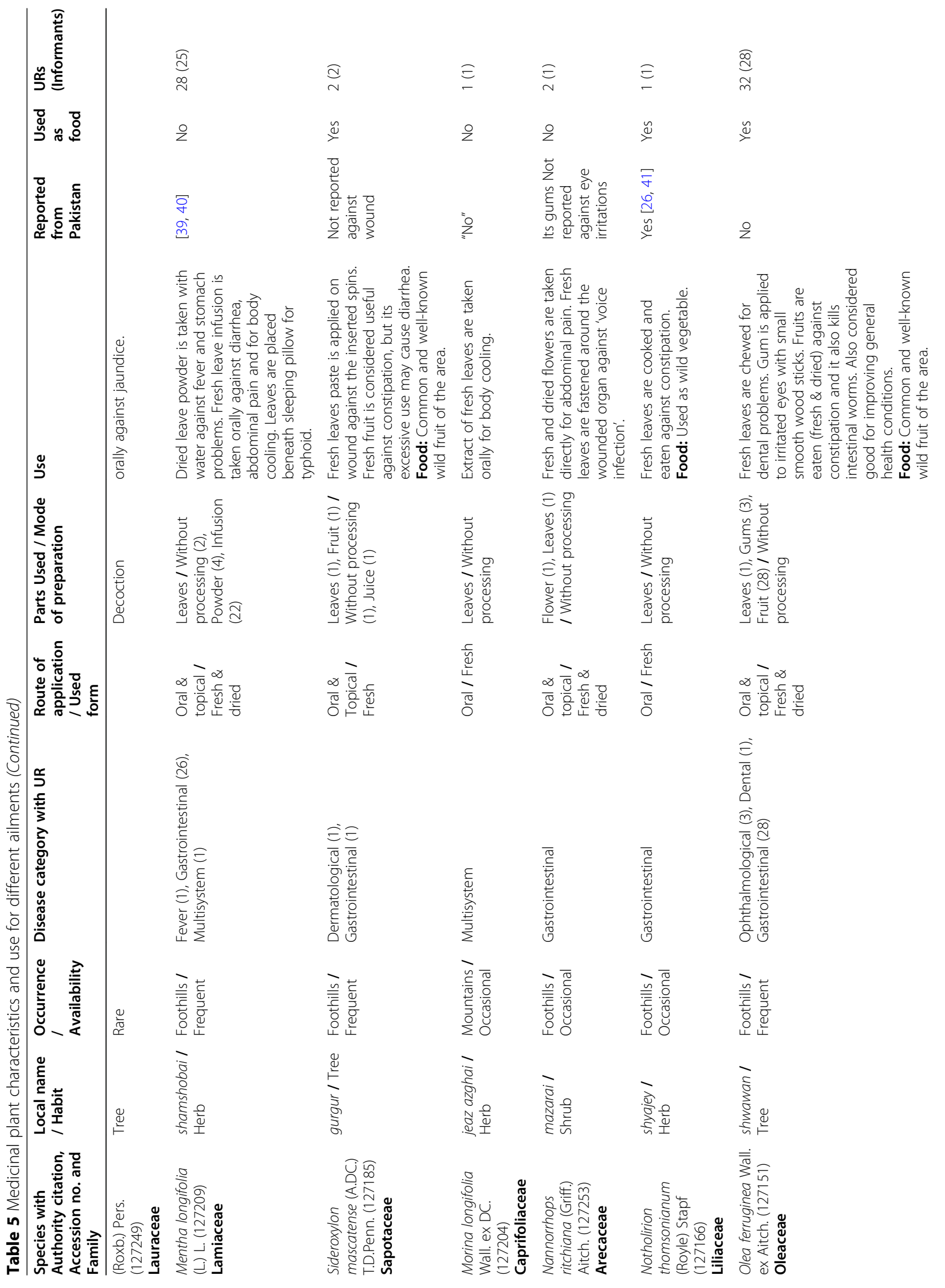




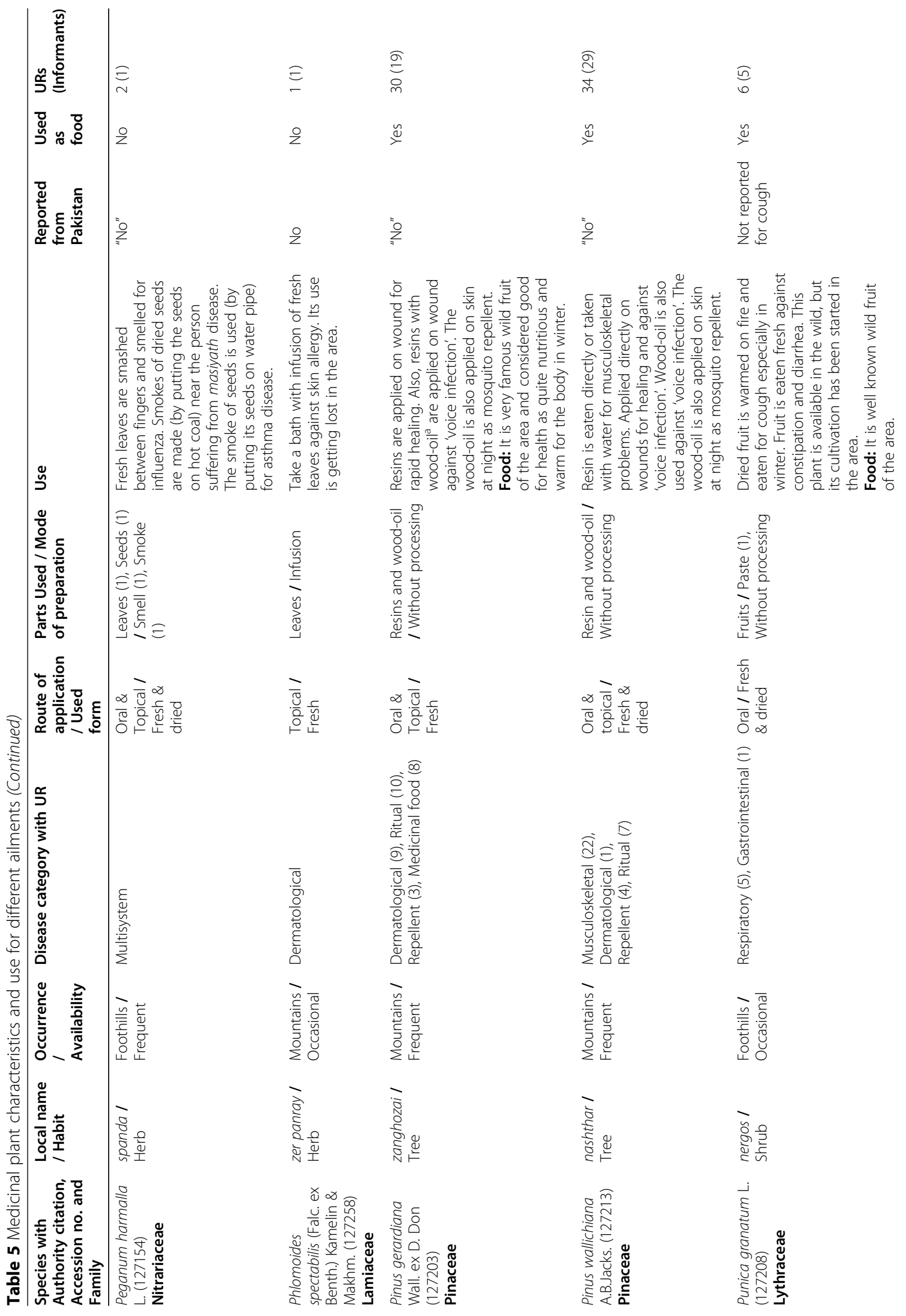




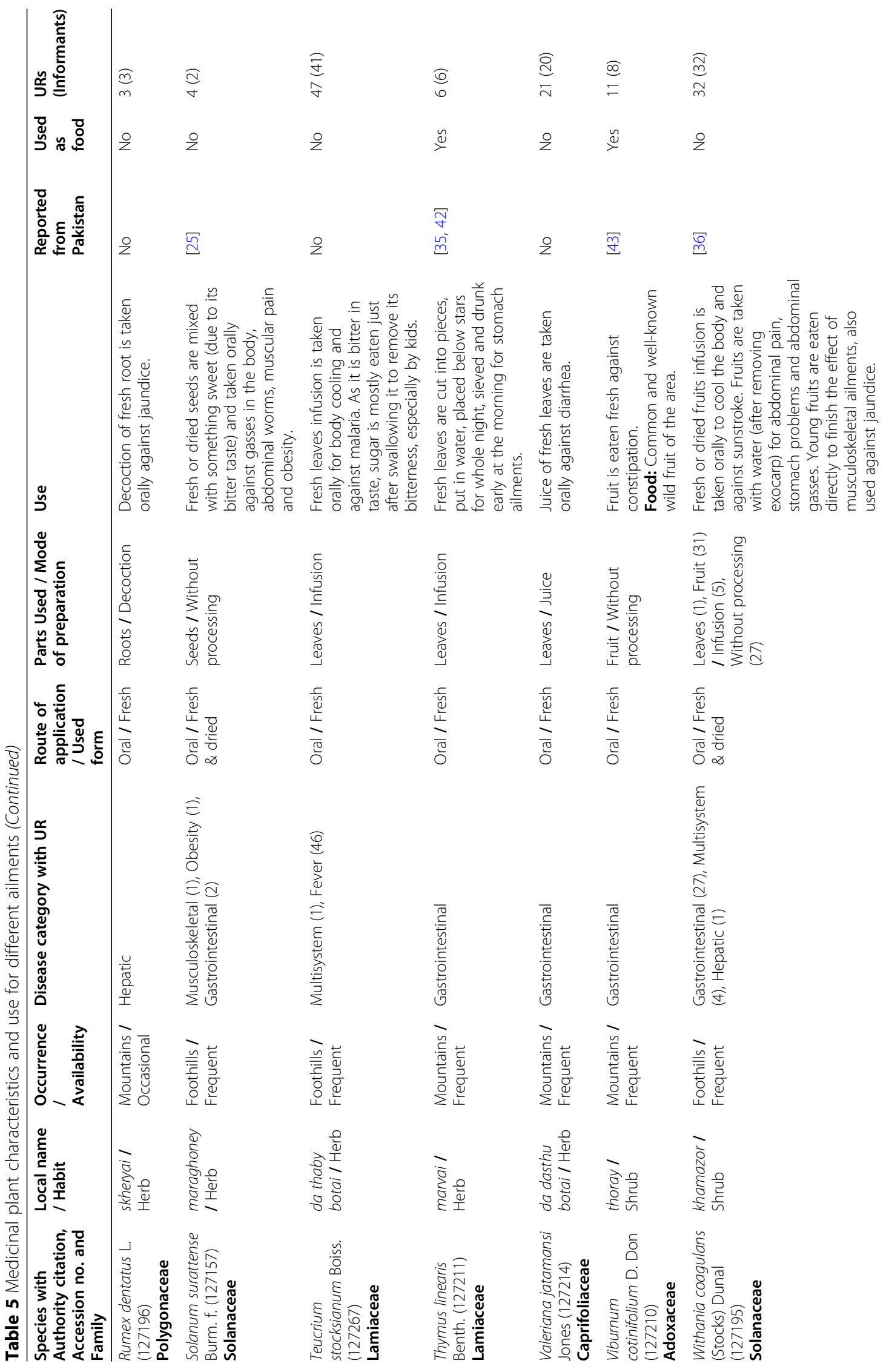




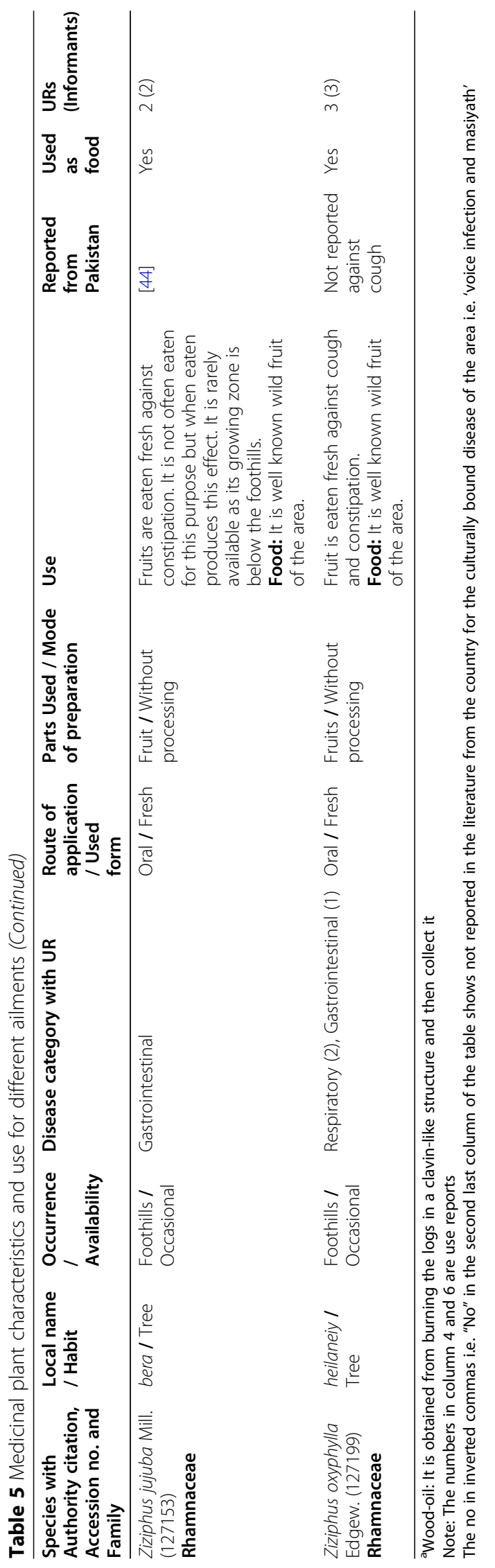




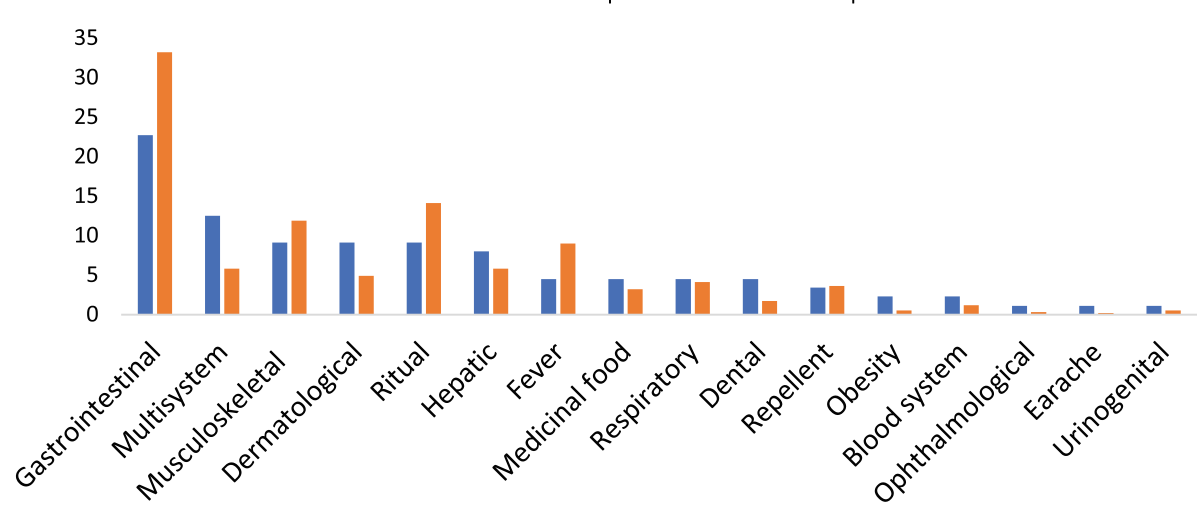

Fig. 2 Medicinal plants used in various disease categories

two species are used for their smell and smoke (Table 5, Fig. 5).

\section{Variation in knowledge among villages and informants} Medicinal plant knowledge is similar among villages (Fig. 6). Three-fourths of all medicinal plant species were mentioned in more than one of the villages, and $15 \mathrm{spp}$. were common to all villages' informants. Also, sheep and goat skins are homogenously used in addition to animal and mineral based materia medica.

A comparison of age groups shows that informants between 20 and 29 years reported less medicinal plants than older people. Medicinal plant knowledge is transmitted vertically, i.e., from generation to generation and horizontally within the community especially among elders.

\section{Discussion}

\section{Prevalent diseases and concepts}

In the present study, gastrointestinal diseases have the highest number of species and use reports, followed by ritual uses and musculoskeletal ailments (number of use reports; Fig. 2). This mirrors the prevalence of diseases and treatments in the area. Gastrointestinal disorders are common usually due to contaminated water, which are preferably treated with medicinal plants. This pattern of treating gastrointestinal disorders with medicinal plants is found all over the world among rural communities and usually explained with the antimicrobial properties of many plants used as medicine [51-53]. Musculoskeletal problems are also common in the area due to the mountainous terrain and accident-prone livelihood activities such as carrying heavy commercial timber.

The category of ritual mainly covers treatments for diseases caused by spirits (Jinn), evil eye or 'voice infection'. The concept of 'voice infection' could not be found in the available scientific literature, although it is deeply rooted in the local understanding of illness and is common in tribal areas of Pakistan and Afghanistan. In contrast, diseases caused by Jinn as well as the concept of evil eye is widely known in Islamic regions and broadly discussed in literature [54-56]. Medical doctors in the nearby area explained that the local concepts of "unusual diseases" seem to be related to epilepsy, psychological problems, and allergies.

Medicinal uses of plant species with a bitter taste like Olea ferrugenia fruits and Caralluma tuberculata aerial

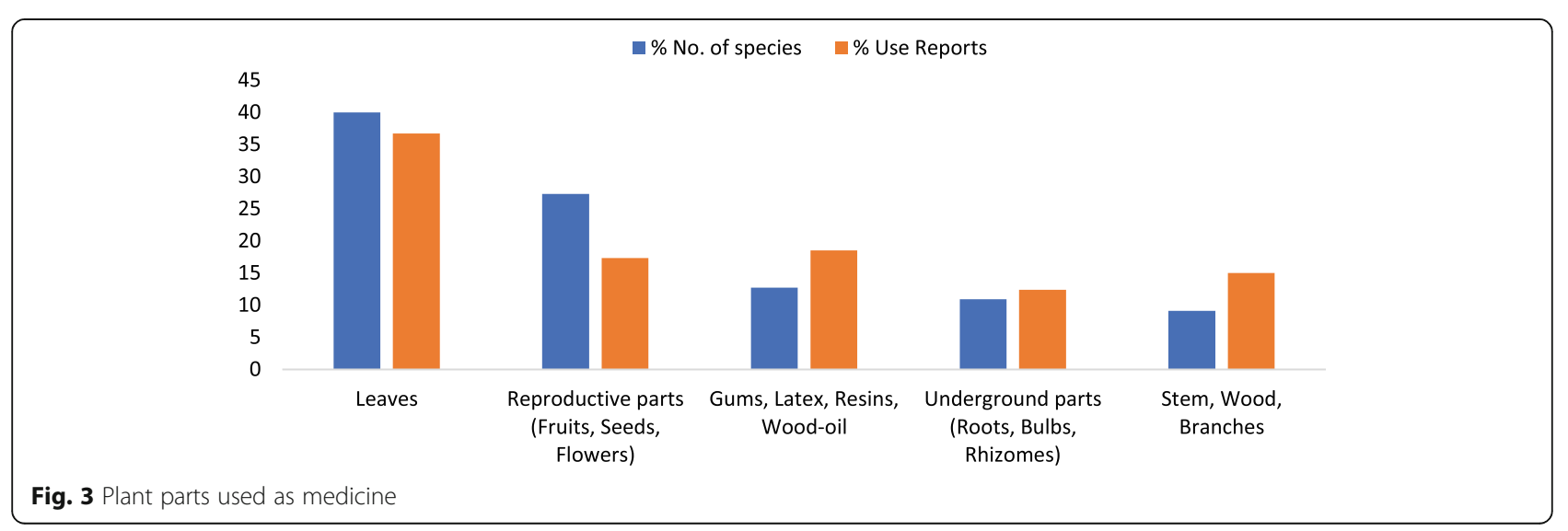




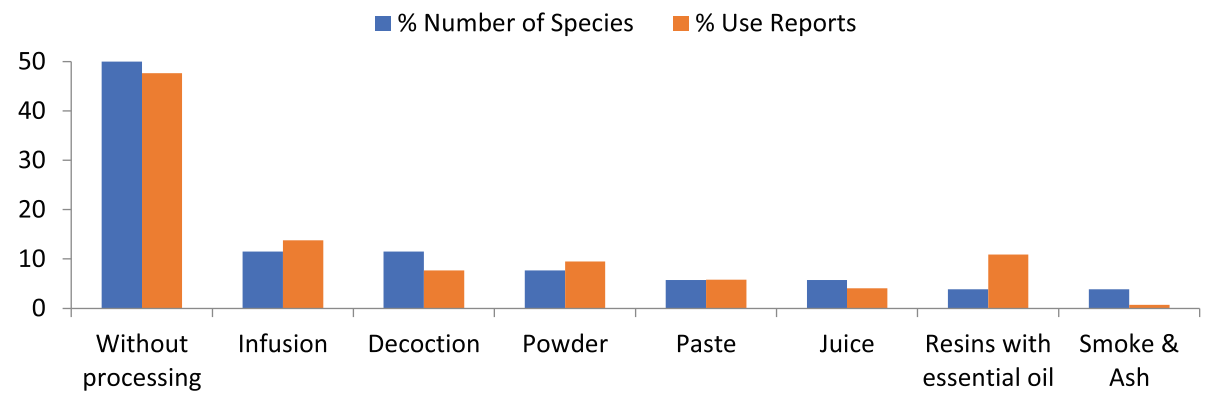

Fig. 4 Various modes of preparation of medicinal plants

parts are based on the concept of 'bitter taste is good for health'. This concept is found in many different cultures of the world [57-59].

Some diseases and medicinal plants are locally perceived as hot and cold, whereas the treatment is based on opposites. For example, malaria is considered a hot disease, and is treated with an infusion of Teucrium stocksianum, which is considered cold. Similarly, a Withania coagulans infusion is considered cold and is used against sunstroke, a locally perceived hot disease. Detailed knowledge about plant parts, preparations, and their degree of hotness and coldness is held and practiced by the herbalist/Hakim/Unani medicine specialists, which, however, is not found in our research area. A hot and cold dichotomy and the treatment with opposites is an integral part of the concept of humours and has been described for other regions of Pakistan $[39,60]$ and all over the globe [61-63].

\section{Local materia medica}

The number of medicinal plant species reported from the Sulaiman area is less than reported by other studies, which typically report between 50 and 150 medicinal plant species for comparable sites [35, 37, 42]. This may have several reasons. Animal products, especially the use of goat and sheep skin, are of utmost importance for local treatments. Furthermore, a substantial part of the remedies is apotropaic and, in this case, often made from minerals or other products. In the Himalayan foothills of Southwest China, a similar situation was found with local healers-among the Shuhi people-who mainly work with ritual plants and their medicinal plant knowledge is relatively scarce compared to other regions [64]. In the Sulaiman area, health prevention through gathered wild food is also important and may be a reason for relatively little medicinal plant knowledge [31]. The numbers of species reported as ethnoveterinary [28] and edible plant species [31] were also less as compared to other areas. Apart from above-mentioned reasons, our research area has semi-arid climatic conditions which support comparatively less plant diversity; andirrespective of most articles on medicinal plants from different parts of the country-we focused on a smaller area but with detailed documentation/evaluation.

All of the documented medicinal plant species are reported from other areas of Pakistan with similar or different uses [30, 36, 37, 40, 41, 65, 66]. Especially the ritual use of some of the species reported for problems like 'voice infection', masiyath, and evil eye (rarely reported as bad eye), seem to be unique to the Sulaiman area and its local culture. Above half of species (52\%) are new or unreported from the country for presently mentioned human ailments (Table 5). Same was the case for ethnoveterinary medicinal plants [28], whereas onethird species of the wild edibles were also newly reported from the study area [31], which shows the uniqueness of

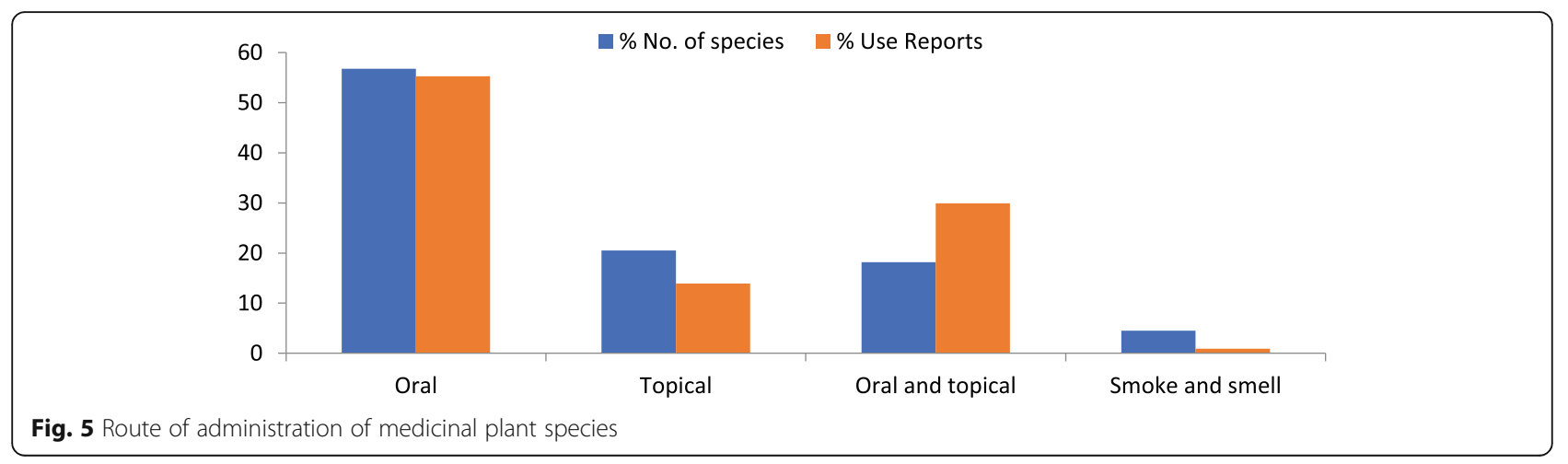




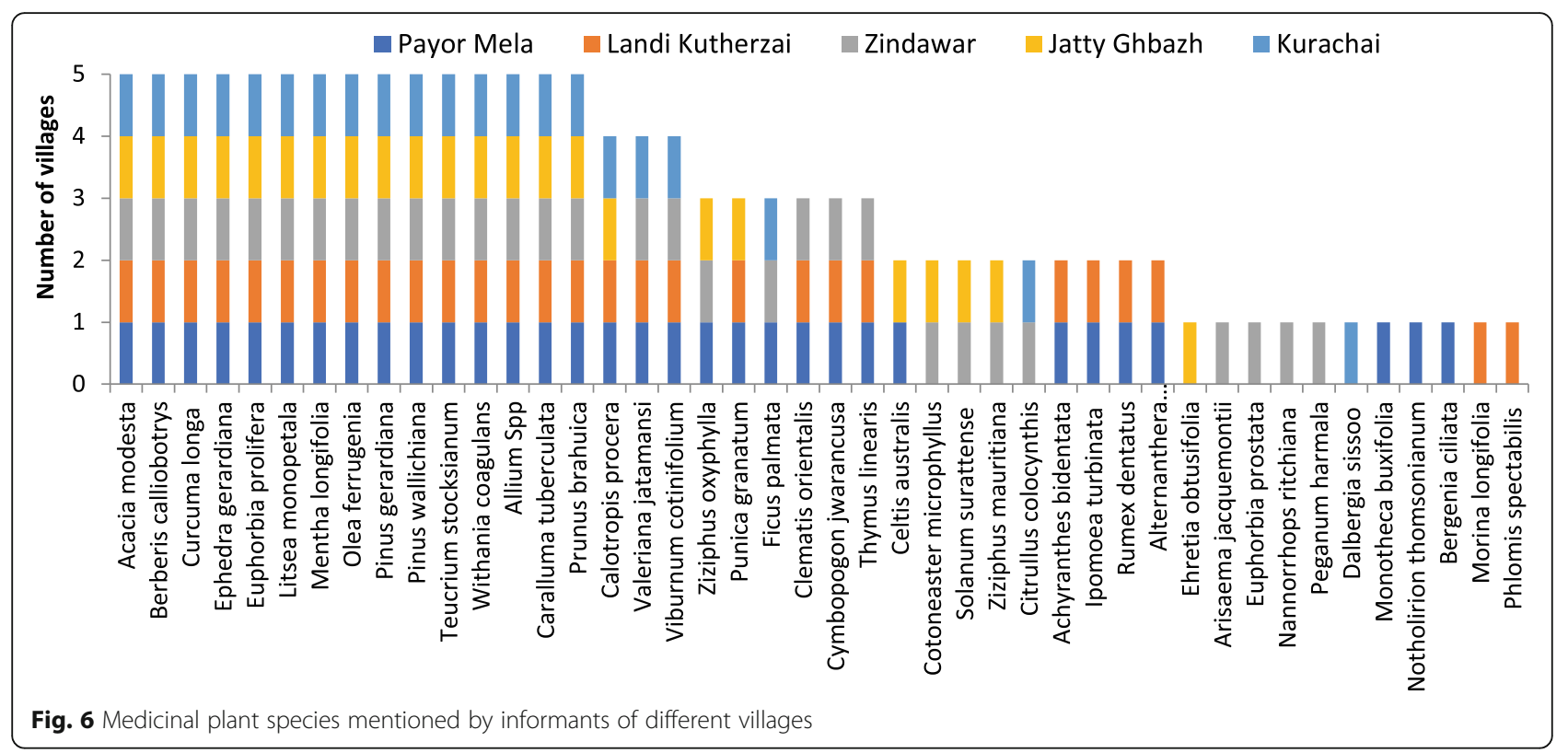

the Sulaiman area and its culture. About half of all use reports were from only 6 plant families, i.e., Lamiaceae (82 UR), Pinaceae (64 UR), Apocynaceae (62 UR), Euphorbiacaee (43 UR), Solanaceae (36 UR) and Rosaceae (23 UR). The relative importance of Pinaceae is due to two Pinus species ( $P$. gerardiana and $P$. wallichiana) which are broadly used in the area not only for medicinal but also for ethnoveterinary medication and food purposes $[28,31]$. The extent of similarity of these results with the prevalence of the families in the local vegetation is unknown, as a checklist of the flora of the Sulaiman Mountains is unavailable.

All reported medicinal plants are used individually without mixing different species or parts together during preparation, and the majority of medicinal plants are directly used without any prior processing/preparation (Fig. 4). There are different medicinal and ritual specialists, but no local herbalists in the area. This coupled with the predominant use of fresh plants, animals and minerals for medicinal purposes indicates that the traditional healing system consists of a combination of knowledge from different systems including biomedicine. A negative impact of syncretism between traditional and biomedicine is that local people tend to use pharmaceuticals like pain killers carelessly since they are unaware of possible side effects and proper dosage. These concepts are unknown to their traditional medicine. The local use of pharmaceuticals based on traditional concepts of plant medicine and related problems have also been described and discussed for two Amazonian societies [57].

Medicinal plant knowledge has some variations between villages (Fig. 6) possibly due to socio-economic differences (Table 1), weaker contacts (horizontal transmission of knowledge), and differences in their exposure to diverse flora [28, 31]. While age-wise knowledge difference (Fig. 7), is a universal phenomenon in traditional medicine, although, in our case it was ubiquitous in all age groups except the young (age 20-29). The commonality of medicinal plant knowledge was relatively more prevalent than the ethnoveterinary species [28] and wild edibles [31]. However, literature supports the commonalities of edible plants knowledge and use-as compared to ethnomedicinal ones-due to the sensitivity of health-related issues/knowledge [67]. Possible reasons include the strong culture of attending/ taking care of patients by the neighboring villagers where they provide/share the best advice/knowledge, which is usually warmly welcomed by the patient's family.

Local medicinal plant use is still dynamic. Some medicinal plants are used less recently while others are newly integrated into the materia medica. Plant medicine might be abandoned due to lack of efficiency, problems of availability, or cheap pharmaceutical alternatives. For example, there was a decrease in the use of Phlomoides spectabilis leaves against human skin allergy. Newly integrated species are Valeriana jatamansi against diarrhea, ca. 10 years ago, and Thymus linearis against stomach problems, ca. 15 years ago. Key informants claimed that the extensive use of few medicinal plants like Teucrium stocksianum, Ephedra gerardiana and Withania coagulans (Table 6)-compared to available pharmaceuticalsis due to their efficacy. Plants with high fidelity levels (e.g., Valeriana jatamansi, Litsea monopetala, Berberis 


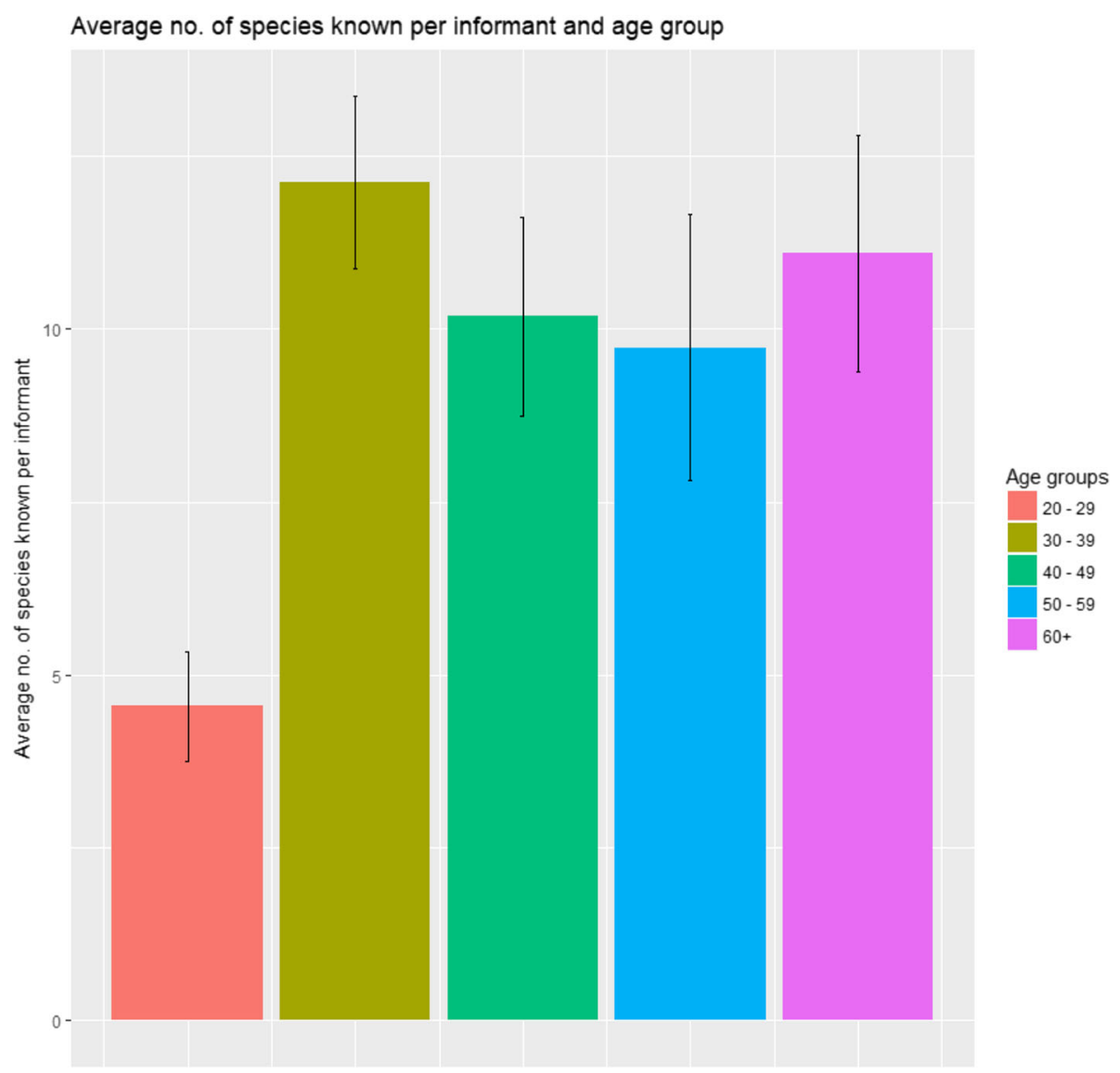

Fig. 7 Age wise variations in medicinal plants knowledge among the inhabitants of the study area

calliobotrys, Withania coagulans and Pinus speciesTable 6) are also used for similar ailments in livestock [28]. The globally increasing tendency of using traditional medicine may led to some harmful/poisonous or unpredictable side effects, e.g., several species mentioned during present study (Euphorbia, Ephedra, Citrullus, etc.) are reported in literature with adverse effects [38, 68, 69]. Therefore, official pharmacopeias must be consulted before using such plants or its parts.

Extensive use of goat and sheep skin for medicinal treatment (Table 4) to our knowledge has not been reported in the ethnomedical literature of Pakistan yet. These uses are not restricted to the present research area but are typically found among Pashtun tribes in Pakistan and Afghanistan (personal discussion with residents of different areas including people of Afghanistan and Pashtun tribes of Pakistan). Similarly, the use of gold, silver and mineral stones against 'voice infection' is also practiced in the adjoining tribal areas (personal observation). These uses of materia medica are transmitted as oral histories. The uses of mineral stone (ده زاغ دان) against 'voice infection' are more important in off seasons when fresh plant material (especially Euphorbia prolifera with fidelity level $100 \%$, Table 6) is scarce.

One of the reasons why the Sulaiman Markhor (Capra falconeri) appears as threatened species on the IUCN Red List 2016 is its high demand for medicinal purposes (e.g., bile of gall bladder for hepatitis, skin for multiple medicinal purposes and meat for general health support). Its horns are used for decoration, and both skin and horns fetch high prices in the market. Sustainable conservation strategy in the form of ecotourism and applying other conservation tools, by involving local communities-as they are familiar with vegetation, habitat and associated wildlife, needs to be devised in the area [43].

Interestingly, no medicinal plant trade is found in the research area. Some species like fruits of Withania coagulance and seeds of Pegnum harmalla are commonly marketed in Pakistan, even in the surrounding communities of the research area, but their prices are unenticing. Other plants like Berberis calliobotrys, Ephedra gerardiana and Velariana jatamansi have a high market demand and catch good prices [44], but locals were unaware about these 
Table 6 Most frequently used plants ( $n=47$ ) for different ailments with their fidelity level (FL)

\begin{tabular}{|c|c|c|c|c|}
\hline Species & Disease & Specific use reports & Total use reports & FL (\%) \\
\hline $\begin{array}{l}\text { Euphorbia prolifera Buch.-Ham. ex D. Don (127159) } \\
\text { Euphorbiaceae }\end{array}$ & 'Voice infection' & 42 & 42 & 100 \\
\hline $\begin{array}{l}\text { Valeriana jatamansi Jones (127214) } \\
\text { Caprifoliaceae }\end{array}$ & Diarrhea & 21 & 21 & 100 \\
\hline $\begin{array}{l}\text { Litsea monopetala (Roxb.) Pers. (127249) } \\
\text { Lauraceae }\end{array}$ & Jaundice & 18 & 18 & 100 \\
\hline $\begin{array}{l}\text { Viburnum cotinifolium D. Don (127210) } \\
\text { Adoxaceae }\end{array}$ & Constipation & 11 & 11 & 100 \\
\hline $\begin{array}{l}\text { Teucrium stocksianum Boiss. (127267) } \\
\text { Lamiaceae }\end{array}$ & Malaria & 46 & 47 & 97.8 \\
\hline $\begin{array}{l}\text { Mentha longifolia (L.) L. (127209) } \\
\text { Lamiaceae }\end{array}$ & Stomach problems and diarrhea & 26 & 28 & 92.8 \\
\hline $\begin{array}{l}\text { Berberis calliobotrys Bien. ex Koehne (127222) } \\
\text { Berberidaceae }\end{array}$ & Musculoskeletal & 24 & 27 & 88.9 \\
\hline $\begin{array}{l}\text { Ephedra gerardiana Wall. ex Stapf. (127150) } \\
\text { Ephedraceae }\end{array}$ & Stomachache & 39 & 44 & 88.6 \\
\hline $\begin{array}{l}\text { Olea ferruginea Wall. ex Aitch. (127151) } \\
\text { Oleaceae }\end{array}$ & Constipation & 28 & 32 & 87.5 \\
\hline $\begin{array}{l}\text { Withania coagulans (Stocks) Dunal (127195) } \\
\text { Solanaceae }\end{array}$ & $\begin{array}{l}\text { Abdominal pain, stomachache, } \\
\text { abdominal gasses }\end{array}$ & 27 & 32 & 84.4 \\
\hline $\begin{array}{l}\text { Acacia modesta Wall. (127146) } \\
\text { Fabaceae }\end{array}$ & Musculoskeletal & 11 & 14 & 78.6 \\
\hline $\begin{array}{l}\text { Prunus brahuica (Boiss.) Aitch. \& Hemsl. (127160) } \\
\text { Rosaceae }\end{array}$ & Snake repellent & 14 & 20 & 70 \\
\hline $\begin{array}{l}\text { Pinus wallichiana A.B.Jacks. (127213) } \\
\text { Pinaceae }\end{array}$ & Musculoskeletal & 22 & 34 & 64 \\
\hline $\begin{array}{l}\text { Calotropis procera (Aiton) Dryand. (127228) } \\
\text { Apocynaceae }\end{array}$ & 'Voice infection' & 16 & 25 & 64 \\
\hline $\begin{array}{l}\text { Curcuma longa L. (127235) } \\
\text { Zingiberaceae }\end{array}$ & Musculoskeletal & 8 & 16 & 50 \\
\hline $\begin{array}{l}\text { Curcuma longa L. (127235) } \\
\text { Zingiberaceae }\end{array}$ & Jaundice & 8 & 16 & 50 \\
\hline $\begin{array}{l}\text { Calotropis procera (Aiton) Dryand. (127228) } \\
\text { Apocynaceae }\end{array}$ & Wounds and abscesses & 9 & 25 & 36 \\
\hline $\begin{array}{l}\text { Pinus gerardiana Wall. ex D. Don (127203) } \\
\text { Pinaceae }\end{array}$ & 'Voice infection' & 10 & 30 & 33 \\
\hline $\begin{array}{l}\text { Caralluma tuberculata N.E. Br. (127133) } \\
\text { Apocynaceae }\end{array}$ & Diabetes & 12 & 37 & 32 \\
\hline $\begin{array}{l}\text { Pinus gerardiana Wall. ex D. Don (127203) } \\
\text { Pinaceae }\end{array}$ & Wound healing & 9 & 30 & 30 \\
\hline
\end{tabular}

commercial values. Sustainable harvesting of such plants could help to improve local livelihoods [70]. Above half of the present ethnomedicinal plant species were commonly available (Table 5), and leaves were the most used parts (Fig. 3), so were less critical for the subsistence needs of the locals. The priority must be given to the rarely available species with higher URs and FL (Table 5-6), because frequent uses decrease its availability. The ethnomedicinal knowledge in the area was also facing degradation- although not very high, which negatively affects the lives and culture of these societies.

\section{Conclusions}

The present paper based on interactions with local informants investigates the traditional medicinal knowledge and materia medica of remote tribal communities in west Pakistan. A variety of medical substances from plants, animals and minerals are used to treat diseases, depending on the severity of the disease and availability of the substance. Treatment often happens in the family context. But different types of medical and ritual specialists are consulted if necessary, especially in the case of unusual diseases and illnesses caused by spirits. The local medicinal system is dynamic as it not only includes 
and integrates new medicinal plants but also pharmaceuticals. However, most important is the use of goat and sheep skin which forms a central pillar for healing. The use and practices mentioned during present study needs detailed pharmaceutical evaluation before its recommendation for general use. The widely used materia medica with rare availability needs conservation priority. Similarly, the local cultural norms are the means of matria medica practices which must be preserved. While the area faces some acculturation processes, traditional practices remain quite intact. From a developmental perspective, reinforcement of local institutional contexts would be important to strengthen local knowledge and related sustainable practices.

\section{Abbreviations}

FATA: Federally administered tribal areas; F.R. D.I: Khan- frontier region of Dera Ismail Khan; URs: Use reports; FL: Fidelity level; DEM: Digital elevation model

\section{Acknowledgments}

We are grateful to the tribal communities of Thakht-e-Sulaiman for their cooperation, hospitality and sharing of knowledge. Our gratitude is extended to Dr. Adnan Ahmad Tahir (Associate Professor, Department of Environmental Sciences, COMSATS University Islamabad, Abbottabad Campus) for developing the DEM and map of the study area. We are also thankful to the reviewers for their time and input in this manuscript.

\section{Authors' contributions}

All authors of this paper have read and approved the final version of the submitted manuscript. KA collected the field data and compiled the 1st draft, MA supervised this project, FKH did the data analysis while CSW finalized the manuscript.

\section{Funding}

No funding source was available for this study.

\section{Availability of data and materials}

The datasets generated and analyzed during the current study are not publicly available due to the easy identification of included participants. However, the corresponding author can be contacted to further explore the data, upon request.

\section{Declarations}

\section{Ethics approval and consent to participate}

All information provided in this paper is based on interview data therefore reflects the local traditional knowledge and practices. The authors did not evaluate the efficacy and toxicity of any remedies.

The study was conducted in accordance to the latest guidelines of the International Society of Ethnobiology. Informed verbal consent was taken from all participants of the study because the study population was mostly unable to understand the written statement.

\section{Consent for publication}

Verbal consent was taken from all the study participants for the publication of results. No written consent was obtained because the study population was mostly unlettered.

\section{Competing interests}

It is declared that the authors have no competing interests.

\section{Author details}

'Department of Environmental Sciences, COMSATS University Islamabad, Abbottabad Campus, Abbottabad, Pakistan. ${ }^{2}$ Department of Plant Sciences, Quaid-i-Azam University Islamabad, Islamabad, Pakistan. ${ }^{3}$ Institute of Systematic and Evolutionary Botany, University of Zurich, Zurich, Switzerland.
Received: 26 August 2020 Accepted: 31 August 2021

Published online: 13 September 2021

\section{References}

1. Moerman DE, Pemberton RW, Kiefer D, Berlin B. A comparative analysis of five medicinal floras. J Ethnobiol. 1999;19(1):49-70.

2. Schippmann U, Leaman D, Cunningham A. A comparison of cultivation and wild collection of medicinal and aromatic plants under sustainability aspects. Frontis. 2006:75-95. https://doi.org/10.1007/1-4020-5449-1_6.

3. Dal Cero M, Saller R, Weckerle CS. The use of the local flora in Switzerland: a comparison of past and recent medicinal plant knowledge. J Ethnopharmacol. 2014;151(1):253-64. https://doi.org/10.1016/j.jep.2013.10.035.

4. Lev E, Amar Z. Ethnopharmacological survey of traditional drugs sold in the kingdom of Jordan. J Ethnopharmacol. 2002;82(2-3):131-45. https://doi. org/10.1016/50378-8741(02)00182-4.

5. Cámara-Leret R, Paniagua-Zambrana N, Balslev H, Macía MJ. Ethnobotanical knowledge is vastly under-documented in northwestern South America. PLoS One. 2014;9(1):e85794. https://doi.org/10.1371/journal.pone.0085794.

6. Yuan $\mathrm{H}, \mathrm{Ma} \mathrm{Q}$, Ye L, Piao G. The traditional medicine and modern medicine from natural products. Molecules. 2016;21(5):559. https://doi.org/10.3390/ molecules21050559.

7. Hamdard. In: Said HM, editor. Hamdard Pharmacopoeia of Eastern Medicine. Karachi, Pakistan: Times Press; 1969.

8. Dharmananda S. Unani medicine with reference to Hamdard of Pakistan and India: ITM; 2004.

9. Williams JT, Ahmad Z. Priorities of Medicinal Plants Research in Pakistan. New Delhi, India: Medicinal and Aromatic Plants Program in Asia (MAPPA); 1999. p. 3-34.

10. Shaikh BT, Hatcher J. Complementary and alternative medicine in Pakistan: prospects and limitations. Evid Based Complement Alternat Med. 2005;2(2): 139-42. https://doi.org/10.1093/ecam/neh088.

11. Shaikh SH, Malik F, James H, Abdul H. Trends in the use of complementary and alternative medicine in Pakistan: a population-based survey. J Altern Complement Med. 2009;15(5):545-50. https://doi.org/10.1089/a cm.2008.0232.

12. Rahman A, Choudhary M. Bioprospecting of medicinal and food plants: Pakistan. New York: UNDP; 2003.

13. Malik F, Hussain D, Dil A, Hannan A, Gilani A. Islamic republic of Pakistan. WHO Global Atlas of Traditional, Complementary and Alternative Medicine (Map Volume) World Health Organization Geneva 2005;165-9.

14. Hussain S, Malik F, Khalid N, Qayyum MA, Riaz H. Alternative and traditional medicines systems in Pakistan: history, regulation, trends, usefulness, challenges, prospects and limitations. A compendium of essays on alternative therapy: IntechOpen; 2012.

15. Shinwari ZK, Qaiser M. Efforts on conservation and sustainable use of medicinal plants of Pakistan. Pak J Bot. 2011;43(1):5-10.

16. Stephenson R, Hennink M. Barriers to family planning service use among the urban poor in Pakistan. Asia Pac Popul J. 2004;19(2):5-26.

17. World Health Organization (WHO): Statistics from WHO's Global Health Observatory, Country Pakistan 2104. https://www.who.int/countries/pak/. Accessed 11 Dec 2019.

18. Khan MA, Khan MA, Hussain M, Ghulam GM. An ethnobotanical inventory of himalayan region poonch valley Azad Kashmir (Pakistan). Ethnobot Res Appl. 2010;8:107-23. https://doi.org/10.17348/era.8.0.107-123.

19. Haq F. The ethno botanical uses of medicinal plants of Allai Valley, Western Himalaya Pakistan. Int J Plant Res. 2012;2(1):21-34. https://doi.org/10.5923/j. plant.20120201.04.

20. Qureshi R, Ghufran M, Sultana K, Ashraf M, Khan A. Ethnomedicinal studies of medicinal plants of Gilgit District and surrounding areas. Ethnobot Res Appl. 2007;5:115-22. https://doi.org/10.17348/era.5.0.115-122.

21. Abbas Q, Qureshi R, Naqvi AUN, Khan SW, Hussain I. Floristic inventory and ethnobotanical study of the Naltar valley (Karakoram range), Gilgit, Pakistan. Pak J Bot. 2013;45:269-77.

22. Abbas Z, Khan SM, Alam J, Khan SW, Abbasi AM. Medicinal plants used by inhabitants of the Shigar Valley, Baltistan region of Karakorum rangePakistan. J Ethnobiol Ethnomed. 2017;13(1):53. https://doi.org/10.1186/s13 002-017-0172-9.

23. Shah SMM, Ullah F, Shah SMH, Zahoor M, Sadiq A. Analysis of chemical constituents and antinociceptive potential of essential oil of Teucrium Stocksianum bioss collected from the north west of Pakistan. BMC Complement Altern Med. 2012;12(1):244. https:/doi.org/10.1186/1472-6882-12-244. 
24. Ali K, Khan N, Rahman I-U, Khan W, Ali M, Uddin N, et al. The ethnobotanical domain of the Swat Valley, Pakistan. J Ethnobiol Ethnomed. 2018;14(1):39. https://doi.org/10.1186/s13002-018-0237-4.

25. Iqbal $\mathrm{H}$, Sher $\mathrm{Z}$, Khan ZU. Medicinal plants from salt range pind dadan khan, District Jhelum, Punjab, Pakistan. J Med Plants Res. 2011;5(11):2157-68.

26. Bibi S, Sultana J, Sultana H, Malik RN. Ethnobotanical uses of medicinal plants in the highlands of Soan Valley, salt range, Pakistan. J Ethnopharmacol. 2014; 155(1):352-61. https://doi.org/10.1016/j.jep.2014.05.031.

27. Raziq A, de Verdier K, Younas M. Ethnoveterinary treatments by dromedary camel herders in the Suleiman mountainous region in Pakistan: an observation and questionnaire study. J Ethnobiol Ethnomed. 2010;6(1):16. https://doi.org/10.1186/1746-4269-6-16.

28. Ahmad K, Ahmad M, Weckerle C. Ethnoveterinary medicinal plant knowledge and practice among the tribal communities of Thakht-eSulaiman hills, West Pakistan. J Ethnopharmacol. 2015;170:275-83. https:// doi.org/10.1016/j.jep.2015.05.022.

29. Government of Pakistan. 6th population \& housing census 2017. In: Statistics PBo, editor. Islamabad, Pakistan 2017.

30. Ahmad K, Ahmad M, Weckerle C. Ethnobotanical studies of the eastern plains of Takht-e-Sulaiman hills. Pak J Bot. 2013;45(S1):197-205.

31. Ahmad K, Pieroni A. Folk knowledge of wild food plants among the tribal communities of Thakht-e-Sulaiman Hills, North-West, Pakistan. J Ethnobiol Ethnomed. 2016;12(1):17. https://doi.org/10.1186/s13002-016-0090-2.

32. Bernard HR. Research methods in anthropology: qualitative and quantitative approaches, Sixth Edition. Lanham, Maryland: Rowman \& Littlefield Publishers. 2017. p. 163-94.

33. Berlin EA, Berlin B. Some field methods in medical ethnobiology. Field Methods. 2005;17(3):235-68. https://doi.org/10.1177/1525822X05277532.

34. International Society of Ethnobiology. ISE Code of Ethics (with 2008 Additions) 2006. URL http://ethnobiology.net/code-of-ethics/ (Accessed 11 December 2019).

35. Haq F, Ahmad H, Alam M. Traditional uses of medicinal plants of Nandiar Khuwarr catchment (district Battagram), Pakistan. J Med Plants Res. 2011;5(1):39-48.

36. Faroog S, Barki A, Yousaf Khan M, Fazal H. Ethnobotanical studies of the flora of tehsil Birmal in South Waziristan Agency, Pakistan. Pak J Weed Sci Res. 2012;18(3):277-91.

37. Alam N, Shinwari Z, llyas M, Ullah Z. Indigenous knowledge of medicinal plants of Chagharzai valley, district Buner, Pakistan. Pak J Bot. 2011;43(2):773-80.

38. Harvard Health Publishing. The dangers of the herb ephedra, 2021. URL https://www.health.harvard.edu/staying-healthy/the-dangers-of-the-herbephedra (Accessed 27 July 2021).

39. Ahmad M, Sultana S, Fazl-i-Hadi S, Ben Hadda T, Rashid S, Zafar M, et al. An ethnobotanical study of medicinal plants in high mountainous region of Chail valley (district swat-Pakistan). J Ethnobiol Ethnomed. 2014;10(1):36. https://doi.org/10.1186/1746-4269-10-36.

40. Shah SM, Hussain F. Ethnomedicinal plant wealth of Mastuj valley, Hindukush range, district Chitral, Pakistan. J Med Plants Res. 2012;6(26):4328-37.

41. Khan N, Ahmed M, Ahmed A, Shaukat S, Wahab M, Ajaib M, et al. Important medicinal plants of chitral gol national park (cgnp) Pakistan. Pak J Bot. 2011; 43(2):797-809.

42. Abbas Z, Khan SM, Abbasi AM, Pieroni A, Ullah Z, labal M, et al. Ethnobotany of the Balti community, Tormik valley, Karakorum range, Baltistan, Pakistan. J Ethnobiol Ethnomed. 2016;12(1):38. https://doi.org/10.11 86/s13002-016-0114-y.

43. Ali S. "Conservation and Status of Markhor (Capra falconeri) in the Northen Parts of Northwest Frontier Province, Pakistan." (2008). Graduate Student Theses, Dissertations, \& Professional Papers. 10919.

44. Sher H, Aldosari A, Ali A, de Boer HJ. Economic benefits of high value medicinal plants to Pakistani communities: an analysis of current practice and potential. J Ethnobiol Ethnomed. 2014;1:71.

45. Nasir E, Ali S. Flora of West Pakistan. Department of Botany. Karachi, Pakistan: University of Karachi, Fakhri printing press; 1970-1995.

46. Ali SI, Qaisar M. Flora of Pakistan. Islamabad: Pakistan Agricultural Research Council; 1995-2010.

47. Chase MW, Christenhusz MJ, Fay MF, Byng JW, Judd WS, Soltis DE, et al. An update of the angiosperm phylogeny group classification for the orders and families of flowering plants: APG IV. Bot J Linn Soc. 2016;181(1):1-20. https://doi.org/10.1111/boj.12385.

48. The Plant List. The Plant List, a working list of all known plant species (2013). Version 1.1. http://www.theplantlist.org. Accessed 11 Dec 2019.
49. Alexiades MN. Collecting ethnobotanical data: an introduction to basic concepts and techniques. Adv Econ Bot. 1996;10:53-96.

50. Staub PO, Geck MS, Weckerle CS, Casu L, Leonti M. Classifying diseases and remedies in ethnomedicine and ethnopharmacology. J Ethnopharmacol. 2015;174:514-9. https://doi.org/10.1016/j.jep.2015.08.051.

51. Alanis A, Calzada F, Cervantes J, Torres J, Ceballos G. Antibacterial properties of some plants used in Mexican traditional medicine for the treatment of gastrointestinal disorders. J Ethnopharmacol. 2005;100(1-2):153-7. https:// doi.org/10.1016/j.jep.2005.02.022.

52. Gilania AH, Rehman AU. Trends in ethnopharmacology. J Ethnopharmacol. 2005;100(1-2):43-9. https://doi.org/10.1016/j.jep.2005.06.001.

53. Sidhu K, Kaur J, Kaur G, Pannu K. Prevention and cure of digestive disorders through the use of medicinal plants. J Hum Ecol. 2007;21(2):113-6. https:// doi.org/10.1080/09709274.2007.11905959.

54. Khalifa N, Hardie T. Possession and jinn. J R Soc Med. 2005;98(8):351-3. https://doi.org/10.1177/014107680509800805.

55. Qamar AH. The concept of the 'evil'and the 'evil eye'in Islam and Islamic faith-healing traditions. J Islamic Thought Civilization. 2013;3(2):44-53. https://doi.org/10.32350/jitc.32.06

56. Khalifa N, Hardie T, Mullick MS. Jinn and psychiatry: comparison of beliefs among Muslims in Dhaka and Leicester. Publications Archive: Royal College of Psychiatrists' Spirituality and Psychiatry Special Interest Group 2012.

57. Shepard GH. A sensory ecology of medicinal plant therapy in two Amazonian societies. Am Anthropol. 2004;106(2):252-66. https://doi.org/10.1 525/aa.2004.106.2.252

58. Heinrich M. Ethnobotany and natural products: the search for new molecules, new treatments of old diseases or a better understanding of indigenous cultures? Curr Top Med Chem. 2003;3(2):141-54. https://doi. org/10.2174/1568026033392570.

59. Johns T. With bitter herbs they shall eat it: chemical ecology and the origins of human diet and medicine. Tuscon: University of Arizona Press; 1990.

60. Pieroni A, Sheikh Q-Z, Ali W, Torry B. Traditional medicines used by Pakistani migrants from Mirpur living in Bradford, Nothern England. Complement Ther Med. 2008;16(2):81-6. https://doi.org/10.1016/j.ctim.2007.03.005.

61. Eigner D, Scholz D. Ferula asa-foetida and Curcuma longa in traditional medical treatment and diet in Nepal. J Ethnopharmacol. 1999;67(1):1-6. https://doi.org/10.1016/\$0378-8741(98)00234-7.

62. Foster GM. Hippocrates' Latin American Legacy. Humoral Medicine in the New World. Langhorne, Gordon and Breach Science Publisher, USA 1994.

63. García-Hernández KY, Vibrans H, Rivas-Guevara M, Aguilar-Contreras A. This plant treats that illness? The hot-cold system and therapeutic procedures mediate medicinal plant use in San Miguel Tulancingo, Oaxaca, Mexico. J Ethnopharmacol. 2015;163:12-30. https://doi.org/10.1016/j.jep.2015.01.001.

64. Weckerle CS, Huber FK, Yongping Y, Weibang S. Plant knowledge of the Shuhi in the Hengduan Mountains, Southwest China. Econ Bot. 2006;60(1): 3-23. https://doi.org/10.1663/0013-0001(2006)60[3:PKOTSI]2.0.CO;2.

65. Gul F, Shinwari ZK, Afzal I. Screening of indigenous knowledge of herbal remedies for skin diseases among local communities of north West Punjab, Pakistan. Pak J Bot. 2012;5:1609-16.

66. Shinwari ZK. Medicinal plants research in Pakistan. J Med Plants Res. 2010; 4(3):161-76.

67. Quave $\mathrm{CL}$, Pieroni A. A reservoir of ethnobotanical knowledge informs resilient food security and health strategies in the Balkans. Nat Plants. 2015; 1(2):14021. https://doi.org/10.1038/nplants.2014.21.

68. Rahimi R, Amin G, Ardekani MRS. A review on Citrullus colocynthis Schrad: from traditional Iranian medicine to modern phytotherapy. J Altern Complement Med. 2012;18(6):551-4. https://doi.org/10.1089/acm.2011.0297.

69. Bhatia H, Manhas RK, Kumar K, Magotra R. Traditional knowledge on poisonous plants of Udhampur district of Jammu and Kashmir, India. J Ethnopharmacol. 2014;152(1):207-16. https://doi.org/10.1016/j.jep.2013.12.058.

70. Robinon M, Zhang $X$. The world medicine situation (traditional medicines: global situation, issues and challenges). Geneva: World Health Organization, Geneva, Switzerland; 2011

\section{Publisher's Note}

Springer Nature remains neutral with regard to jurisdictional claims in published maps and institutional affiliations. 